Water Availability and Use Science Program

Prepared in cooperation with the Mississippi Department of Environmental Quality, the Yazoo Mississippi Delta Joint Water Management District, and the Arkansas Natural Resources Commission

\title{
Aquaculture and Irrigation Water-Use Model (AIWUM) Version 1.0-An Agricultural Water-Use Model Developed for the Mississippi Alluvial Plain, 1999-2017
}

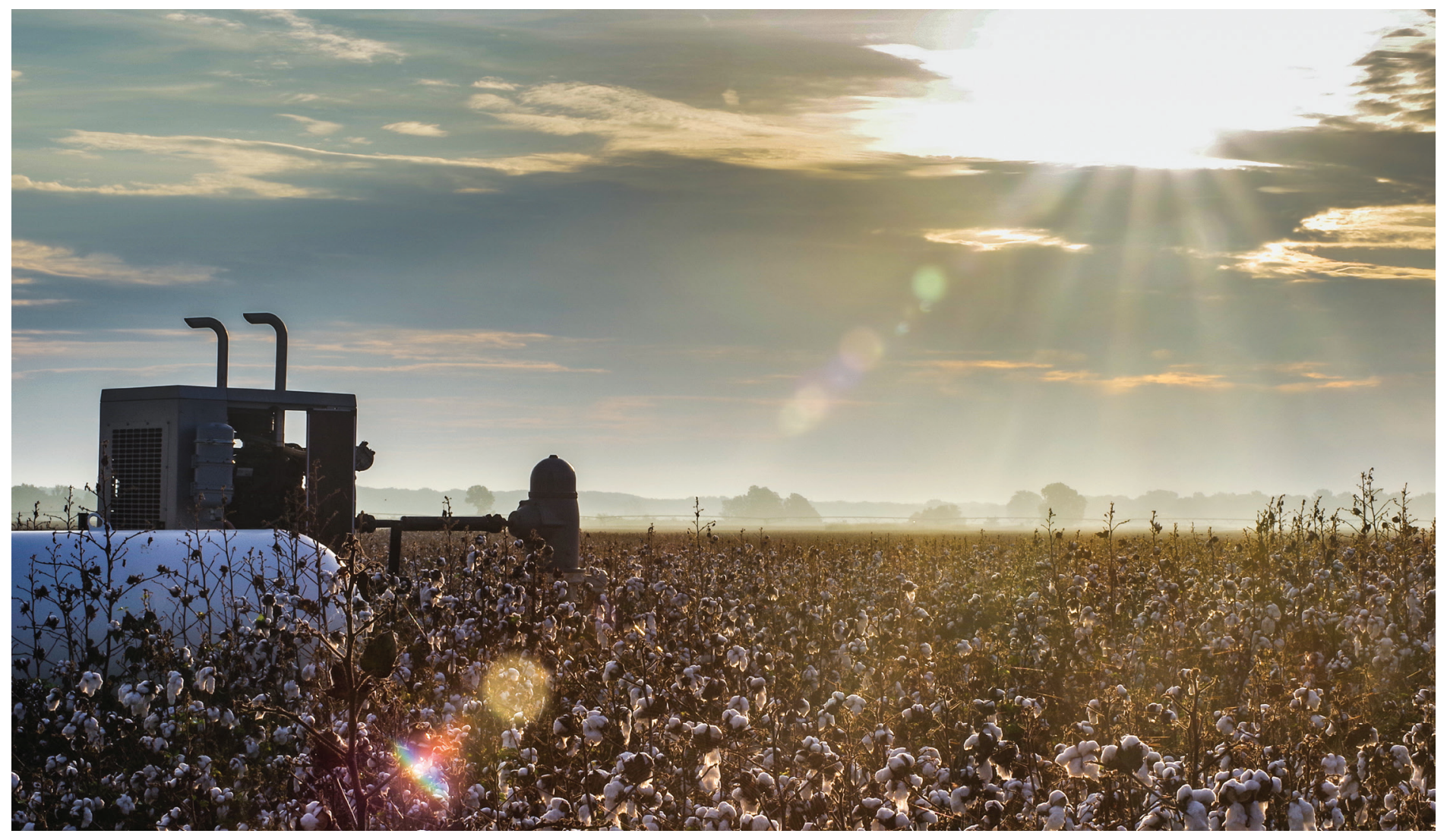

Scientific Investigations Report 2021-5011 
Cover. Cotton field, 2019, Leflore County, Mississippi. Located near U.S. Geological Survey wateruse site 333628090152801 MS-GW-39110 LEFLORE WU (https://waterdata.usgs.gov/nwis/uv?site_ no $=333628090152801$ ). Photograph by Shane J. Stocks, U.S. Geological Survey 


\section{Aquaculture and Irrigation Water-Use Model (AIWUM) Version 1.0-An Agricultural Water-Use Model Developed for the Mississippi Alluvial Plain, 1999-2017}

By Jordan L. Wilson

Water Availability and Use Science Program

Prepared in cooperation with the Mississippi Department of Environmental Quality, the Yazoo Mississippi Delta Joint Water Management District, and the Arkansas Natural Resources Commission

Scientific Investigations Report 2021-5011 


\section{U.S. Geological Survey, Reston, Virginia: 2021}

For more information on the USGS - the Federal source for science about the Earth, its natural and living resources, natural hazards, and the environment—visit https://www.usgs.gov or call 1-888-ASK-USGS.

For an overview of USGS information products, including maps, imagery, and publications, visit https://store.usgs.gov/.

Any use of trade, firm, or product names is for descriptive purposes only and does not imply endorsement by the U.S. Government.

Although this information product, for the most part, is in the public domain, it also may contain copyrighted materials as noted in the text. Permission to reproduce copyrighted items must be secured from the copyright owner.

Suggested citation:

Wilson, J.L., 2021, Aquaculture and Irrigation Water-Use Model (AIWUM) version 1.0-An agricultural water-use model developed for the Mississippi Alluvial Plain, 1999-2017: U.S. Geological Survey Scientific Investigations Report 2021-5011, 36 p., https://doi.org/10.3133/sir20215011.

Associated data for this publication:

Falcone, J.A., and LaMotte, A.E., 2016, National 1-kilometer rasters of selected Census of Agriculture statistics allocated to land use for the time period 1950 to 2012: U.S. Geological Survey data release, https://doi.org/10.5066/F70R 9MHS.

U.S. Geological Survey, 2019a, USGS Water Data for the Nation: U.S. Geological Survey National Water Information System database, accessed May 10, 2018, at http://doi.org/10.5066/F7P55KJN.

U.S. Geological Survey, 2019b, National Hydrography Dataset (ver. USGS National Hydrography Dataset Best Resolution [NHD] for Hydrologic Unit [HU] 4 - 2001 [published 20191002]): USGS National Hydrography web page, accessed November 20, 2020, at https://www.usgs.gov/core-science-systems/ngp/national-hydrography/accessnational-hydrography-products.

Wilson, J.L., 2021, Aquaculture and Irrigation Water-Use Model (AIWUM) version 1.0 estimates and related datasets for the Mississippi Alluvial Plain, 1999-2017: U.S. Geological Survey data release, https://doi.org/10.5066/ P9JM09G4.

ISSN 2328-0328 (online) 


\section{Acknowledgments}

This work was funded by the Water Availability and Use Science Program of the U.S. Geological Survey and conducted in cooperation with the Mississippi Department of Environmental Quality, the Yazoo Mississippi Delta Joint Water Management District, and the Arkansas Natural Resources Commission. 



\section{Contents}

Acknowledgments ……...................................................................................................................

Abstract

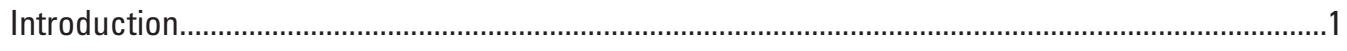

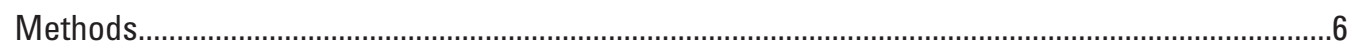

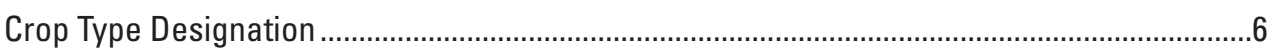

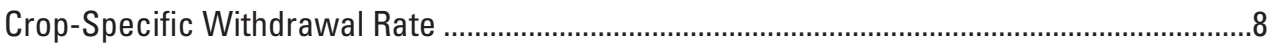

Annual Crop-Specific Withdrawal Rates from the Mississippi Department of Environmental Quality Delta Voluntary Metering Program .................................9

Monthly and Annual Crop-Specific Withdrawal Rates from the Yazoo Mississippi Delta Joint Water Management District..............................................

Distribution of Monthly Crop-Specific Withdrawal Rates ................................................10

Spatio-Climatic Withdrawal Rates................................................................................10

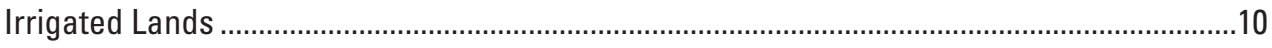

Comparisons of Estimates with Other Models...........................................................................14

U.S. Geological Survey 5-Year Water-Use Compilations ..........................................................14

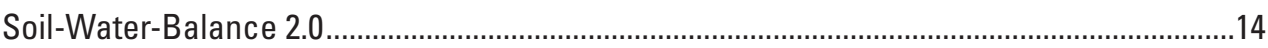

Mississippi Embayment Regional Aquifer Study Groundwater Models...............................14

Aquaculture and Irrigation Water-Use in the Mississippi Alluvial Plain, 1999-2017.......................15

Comparison to USGS 5-Year Water-Use Compilations.........................................................15

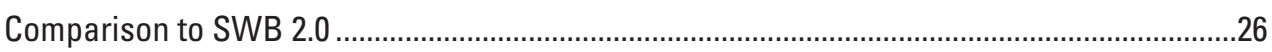

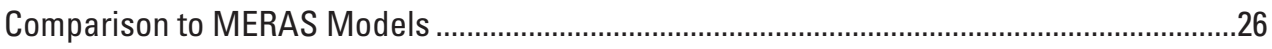

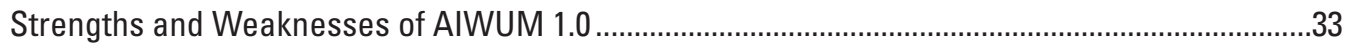

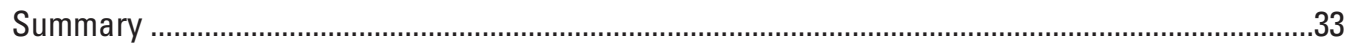

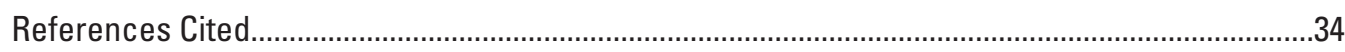

\section{Figures}

1. Map showing the extent of the Mississippi Alluvial Plain, the Mississippi River Valley alluvial aquifer, and the Mississippi Delta ...............................................................

2. Figure showing depiction of the Aquaculture and Irrigation Water-Use Model version 1.0 workflow. ...............................................................................................7

3. Graphs showing monthly crop-specific withdrawal rates from Yazoo Mississippi Delta Joint Water Management District data. ...........................................11

4. Map showing spatio-climatic zones and flowmeter locations and type within the Mississippi Delta and the Mississippi Alluvial Plain study area, 2015 ......................12

5. Map showing estimated total aquaculture and irrigation water use for the Mississippi Alluvial Plain study area.

6. Map showing estimated water use for aquaculture for the Mississippi Alluvial Plain study area ......................................................................................................18

7. Map showing estimated water use for rice for the Mississippi Alluvial Plain study area

8. Map showing estimated water use for soybeans for the Mississippi Alluvial Plain study area 
9. Map showing estimated water use for corn for the Mississippi Alluvial Plain study area

10. Map showing estimated water use for cotton for the Mississippi Alluvial Plain study area

11. Map showing estimated water use for all other crops for the Mississippi Alluvial Plain study area.

12. Figure showing total water-use estimates for the Mississippi Alluvial Plain study area from the Mississippi Embayment Regional Aquifer Study (MERAS) 2.0, MERAS version 2.1, Soil-Water-Balance 2.0, Aquaculture and Irrigation Water-Use Model 1.0, and USGS 5-year compilations, 1999 through 2017.

13. Map showing percent difference between county-level estimated aquaculture and irrigation water use and irrigated area from Aquaculture and Irrigation Water-Use Model 1.0 and compiled, estimated water use from the U.S. Geological Survey 5-year compilations for the Mississippi Alluvial Plain study area.

14. Graph showing median percent differences of total water use between Aquaculture and Irrigation Water-Use Model 1.0 and Soil-Water-Balance 2.0 and Mississippi Embayment Regional Aquifer Study models

15. Maps showing percent difference between estimated water use from Aquaculture and Irrigation Water-Use Model 1.0 and Soil-Water-Balance 2.0 during the growing season, 2006

16. Graph showing percent difference for April through June and July through September 2006 between estimated water use from Aquaculture and Irrigation Water-Use Model 1.0 and parameterized groundwater withdrawal

\section{Tables}

1. Characteristics of AIWUM 1.0 and independent estimates of aquaculture and irrigation water use

2. Annual crop-specific withdrawal rates, in acre-feet per acre, within each spatio-climatic zone, 2014 through 2017.

3. Median precipitation values, annual applied withdrawal rates, and total estimated water use for each model year for the Mississippi Alluvial Plain study area, 1999 through 2017.

4. Annual total area and water use and annual percentage of total crop area and water use for aquaculture, corn, cotton, other crops, rice, and soybeans in the Mississippi Alluvial Plain, 1999 through 2017.

\section{Conversion Factors}

U.S. customary Units to International System of Units

\begin{tabular}{llll}
\hline & Multiply & \multicolumn{1}{c}{ By } & \multicolumn{1}{c}{ To obtain } \\
\hline & \multicolumn{1}{c}{ Length } & \\
\hline foot (ft) & 0.3048 & meter $(\mathrm{m})$ & \\
mile (mi) & 1.609 & kilometer $(\mathrm{km})$ & \\
\hline
\end{tabular}




\begin{tabular}{|c|c|c|}
\hline Multiply & By & To obtain \\
\hline \multicolumn{3}{|c|}{ Area } \\
\hline acre & 4,047 & square meter $\left(\mathrm{m}^{2}\right)$ \\
\hline acre & 0.004047 & square kilometer $\left(\mathrm{km}^{2}\right)$ \\
\hline square foot $\left(\mathrm{ft}^{2}\right)$ & 0.09290 & square meter $\left(\mathrm{m}^{2}\right)$ \\
\hline square inch $\left(\right.$ in $\left.^{2}\right)$ & 6.452 & square centimeter $\left(\mathrm{cm}^{2}\right)$ \\
\hline square mile $\left(\mathrm{mi}^{2}\right)$ & 259.0 & hectare (ha) \\
\hline square mile $\left(\mathrm{mi}^{2}\right)$ & 2.590 & square kilometer $\left(\mathrm{km}^{2}\right)$ \\
\hline \multicolumn{3}{|c|}{ Volume } \\
\hline gallon (gal) & 0.003785 & cubic meter $\left(\mathrm{m}^{3}\right)$ \\
\hline million gallons (Mgal) & 3,785 & cubic meter $\left(\mathrm{m}^{3}\right)$ \\
\hline cubic foot $\left(\mathrm{ft}^{3}\right)$ & 0.02832 & cubic meter $\left(\mathrm{m}^{3}\right)$ \\
\hline cubic yard $\left(\mathrm{yd}^{3}\right)$ & 0.7646 & cubic meter $\left(\mathrm{m}^{3}\right)$ \\
\hline cubic mile $\left(\mathrm{mi}^{3}\right)$ & 4.168 & cubic kilometer $\left(\mathrm{km}^{3}\right)$ \\
\hline acre-foot (acre-ft) & 1,233 & cubic meter $\left(\mathrm{m}^{3}\right)$ \\
\hline \multicolumn{3}{|c|}{ Flow rate } \\
\hline acre-foot per year (acre-ft/yr) & 1,233 & cubic meter per year $\left(\mathrm{m}^{3} / \mathrm{yr}\right)$ \\
\hline cubic foot per day $(\mathrm{ft} 3 / \mathrm{d})$ & 0.02832 & cubic meter per day $\left(\mathrm{m}^{3} / \mathrm{d}\right)$ \\
\hline gallon per day (gal/d) & 0.003785 & cubic meter per day $\left(\mathrm{m}^{3} / \mathrm{d}\right)$ \\
\hline \multicolumn{3}{|c|}{ International System of Units to U.S. customary units } \\
\hline Multiply & By & To obtain \\
\hline \multicolumn{3}{|c|}{ Length } \\
\hline meter $(\mathrm{m})$ & 3.281 & foot $(\mathrm{ft})$ \\
\hline kilometer $(\mathrm{km})$ & 0.6214 & mile (mi) \\
\hline \multicolumn{3}{|c|}{ Area } \\
\hline square meter $\left(\mathrm{m}^{2}\right)$ & 0.0002471 & acre \\
\hline square kilometer $\left(\mathrm{km}^{2}\right)$ & 247.1 & acre \\
\hline square meter $\left(\mathrm{m}^{2}\right)$ & 10.76 & square foot $\left(\mathrm{ft}^{2}\right)$ \\
\hline square kilometer $\left(\mathrm{km}^{2}\right)$ & 0.3861 & square mile $\left(\mathrm{mi}^{2}\right)$ \\
\hline \multicolumn{3}{|c|}{ Volume } \\
\hline cubic meter $\left(\mathrm{m}^{3}\right)$ & 264.2 & gallon (gal) \\
\hline cubic meter $\left(\mathrm{m}^{3}\right)$ & 0.0002642 & million gallons (Mgal) \\
\hline cubic meter $\left(\mathrm{m}^{3}\right)$ & 0.0008107 & acre-foot (acre-ft) \\
\hline \multicolumn{3}{|c|}{ Flow rate } \\
\hline cubic meter per second (m3/s) & 70.07 & acre-foot per day (acre-ft/d) \\
\hline cubic meter per year $\left(\mathrm{m}^{3 /} / \mathrm{yr}\right)$ & 0.000811 & acre-foot per year (acre-ft/yr) \\
\hline cubic meter per day $\left(\mathrm{m}^{3} / \mathrm{d}\right)$ & 35.31 & cubic foot per day ( $\left.\mathrm{ft}^{3} / \mathrm{d}\right)$ \\
\hline cubic meter per day $\left(\mathrm{m}^{3} / \mathrm{d}\right)$ & 264.2 & gallon per day (gal/d) \\
\hline cubic meter per second $\left(\mathrm{m}^{3} / \mathrm{s}\right)$ & 22.83 & million gallons per day $(\mathrm{Mgal} / \mathrm{d})$ \\
\hline
\end{tabular}




\title{
Datum
}

Vertical coordinate information is referenced to the North American Vertical Datum of 1988 (NAVD 88).

Horizontal coordinate information is referenced to the North American Datum of 1983 (NAD 83).

Altitude, as used in this report, refers to distance above the vertical datum.

\section{Abbreviations}

\author{
AIWUM Aquaculture and Irrigation Water-Use Model \\ CDL cropland data layer \\ CONUS conterminous United States \\ DVMP Delta Voluntary Metering Program \\ FAO Food and Agriculture Organization \\ MAP Mississippi Alluvial Plain \\ MDEO Mississippi Department of Environmental Quality \\ MERAS Mississippi Embayment Regional Aquifer Study \\ MIrAD-US Moderate Resolution Imaging Spectroradiometer Irrigated Agriculture Dataset for \\ the United States \\ MODIS Moderate Resolution Imaging Spectroradiometer \\ NetCDF Network Common Data Form \\ NHD National Hydrography Dataset \\ PD percent difference \\ SWB Soil-Water-Balance \\ USDA U.S. Department of Agriculture \\ USGS U.S. Geological Survey \\ YMD Yazoo Mississippi Delta Joint Water Management District
}




\title{
Aquaculture and Irrigation Water-Use Model (AIWUM) Version 1.0-An Agricultural Water-Use Model Developed for the Mississippi Alluvial Plain, 1999-2017
}

\author{
By Jordan L. Wilson
}

\section{Abstract}

Water use is a critical and often uncertain component of quantifying any water budget and securing reliable and sustainable water supplies. Recent water-level declines in the Mississippi Alluvial Plain (MAP), especially in the central part of the Mississippi Delta, pose a threat to water sustainability. Aquaculture and Irrigation Water-Use Model (AIWUM) 1.0, one of the first national agricultural water-use models that provides water use at the scale of most groundwater models, was developed and compared to other reported and estimated aquaculture and irrigation water-use values within the MAP study area for 1999 through 2017 to improve water-use estimates needed as input to a hydrologic decision-support system in the MAP. Results indicate annual total water-use estimates from 1999 through 2017 ranged from about 5 to 13 billion gallons per day and, on average, a majority of the water use was applied to rice (about 51 percent), followed by soybeans (about 26 percent), and less than $(<) 10$ percent each was applied to aquaculture, corn, cotton, and other crops. Comparisons indicated that annual total water-use estimates from AIWUM 1.0 were smaller than or comparable to all other sources of water-use data. Although there is disagreement at the monthly timescale in estimates in the Mississippi Delta within each part of the growing season, the annual total water use is comparable between AIWUM 1.0 and the Mississippi Embayment Regional Aquifer Study groundwater model 2.1. Estimates from AIWUM 1.0 could be used in models at all scales (for example, local, regional, national) and could provide a nationally consistent methodology in estimating water use driven by regional crop-specific withdrawal rates.

\section{Introduction}

In a recent assessment of the U.S. Geological Survey's future water priorities, the National Academy of Sciences identified the 6 global and interdisciplinary water science and resource challenges of the next 25 years as: (1) understanding the role of water in the Earth system, (2) quantifying the water cycle, (3) developing integrated modeling, (4) quantifying change in the sociohydrological system, (5) securing reliable and sustainable water supplies, and (6) understanding and predicting water-related hazards (National Academies of Sciences, Engineering, and Medicine, 2018). Understanding and quantifying water use is a critical and often uncertain component of these challenges. Water use, defined in this report as withdrawal of groundwater for agricultural (aquaculture [water that is used to farm organisms that live in water] and irrigation [water that is applied by an irrigation system]) purposes, is also typically the largest driver of applicationoriented hydrologic models used to evaluate watermanagement scenarios and optimize spatial and temporal frequency of monitoring networks (Demissie and others, 2015). Uncertainties in water-use estimates translate to uncertainties in model prediction, reducing the utility of these models. It is necessary to develop more robust water-use monitoring and modeling methods to fully realize the potential of applicationoriented hydrologic decision-support systems, which are needed to enable water resource managers to quickly assess a variety of scenarios and potential implications, including economic considerations.

Currently (2021), the U.S. Geological Survey (USGS) Water Availability and Use Science Program is developing a hydrologic decision-support system to help manage water resources in the Mississippi Alluvial Plain (MAP; fig. 1) one of the most productive agricultural regions in the Nation. Groundwater in the Mississippi River Valley alluvial aquifer (fig. 1) is the dominant source of water for aquaculture and irrigation purposes in the MAP (Kebede and others, 2014; Alhassan and others, 2019) with an estimated average withdrawal of more than 9 billion gallons per day or more than 3 trillion gallons annually (Maupin and Barber, 2005). Therefore, water use is an important component in the hydrologic decision-support system. In recent years, water-level declines have been observed, especially in the northwestern MAP, locally referred to as the Mississippi Delta (Barlow and Clark, 2011; fig. 1). Population in the United States, which drives agricultural demand and water resources, is projected to grow by approximately 98 million people between 2014 and 


\section{Aquaculture and Irrigation Water-Use Model (AIWUM) Version 1.0}

2060 (Colby and Ortman, 2015), potentially further exacerbating water sustainability issues in the MAP region and nationally.

To improve upon the county-scale water-use estimates used as input in previous groundwater models, Aquaculture and Irrigation Water-Use Model (AIWUM) 1.0 was developed. Estimates from AIWUM 1.0 improve water withdrawal estimates for aquaculture and irrigation purposes needed as input to a hydrologic decision-support system and provide a framework for future water-use monitoring and modeling efforts. Because the amount of water applied to the surface for agricultural purposes is consumed by the crop, lost via evapotranspiration, or returned to the subsurface, estimates from AIWUM 1.0 represent a combination of crop consumption and evapotranspiration, and the amount of recharge to the aquifer must be estimated separately, such as with the Soil-WaterBalance (SWB) 2.0 code (Westenbroek and others, 2018), which is the current practice of the MAP study. Although AIWUM was calibrated to the MAP study area, it could provide uncalibrated estimates anywhere within the conterminous United States (CONUS).

This report focuses on application of AIWUM 1.0 in the MAP study area to assess its relative accuracy to data and independent estimates of aquaculture and irrigation water use available in the MAP study area, including water withdrawal estimated from SWB 2.0, water withdrawal estimates used in the calibration of the Mississippi Embayment Regional Aquifer Study (MERAS) versions 2.0 (Clark and Hart, 2009) and 2.1 (Haugh and others, 2019) groundwater models, and reported water-use estimates contained in the USGS's 5-year water-use compilations. A comparison of characteristics of AIWUM 1.0 and these models and datasets can be found in table 1. The substantial benefits and limitations of using AIWUM 1.0 are also discussed. 


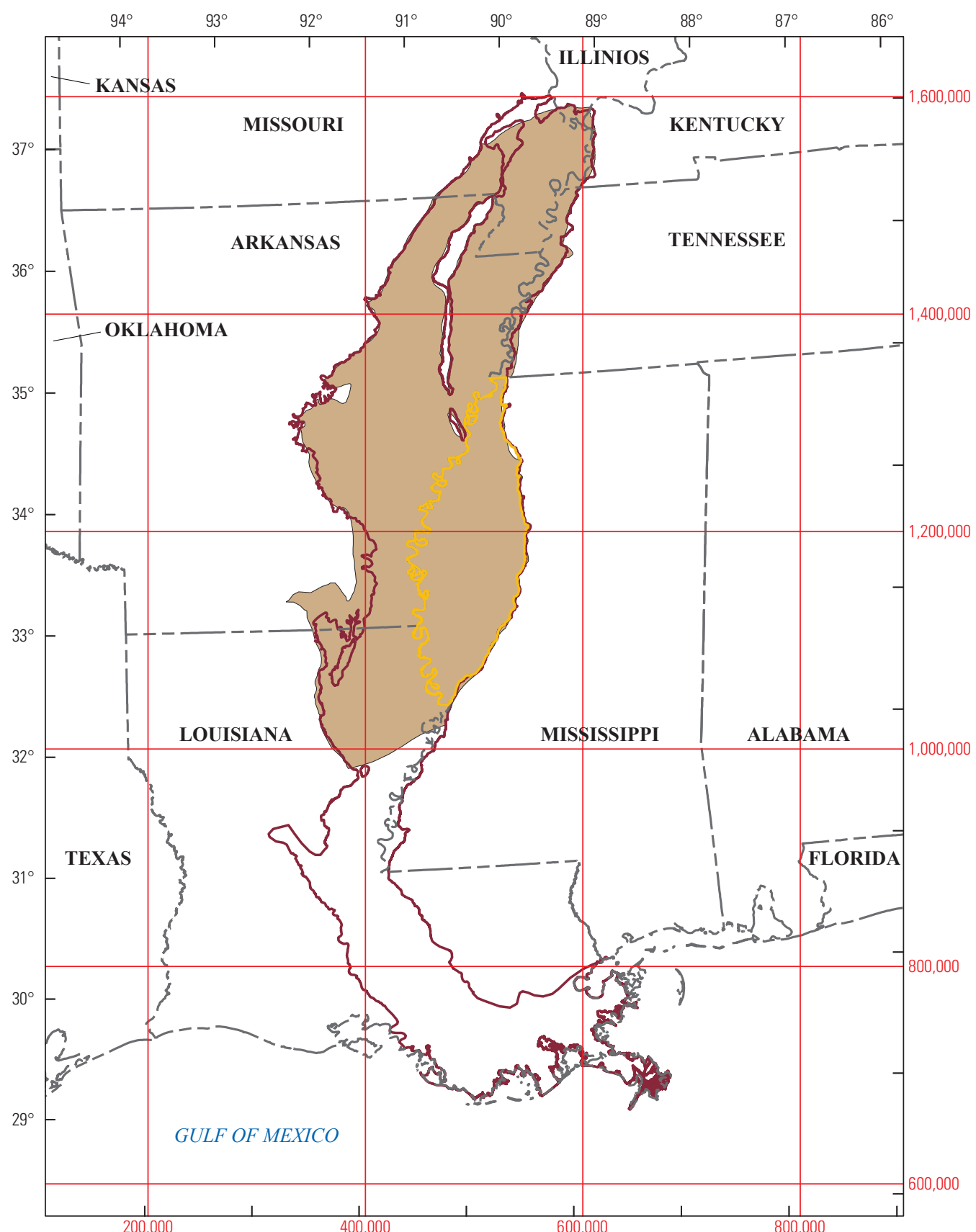

\section{EXPLANATION}

Mississippi River Valley alluvial aquifer

Mississippi Alluvia Plain boundary

Mississippi Delta boundary

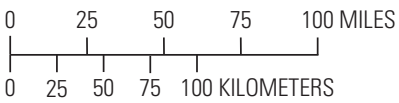

Base modified from U.S. Census Bureau digital data, 1:500,000, 2015

Standard parallels $29^{\circ} 30^{\prime} \mathrm{N}$. and $45^{\circ} 30^{\prime} \mathrm{N}$., central meridian $96^{\circ} \mathrm{W}$.

Secondary grid displays Albers Equal-Area Conic projection, in meters

Horizontal coordinate information referenced to the North American Datum of 1983 (NAD 83)

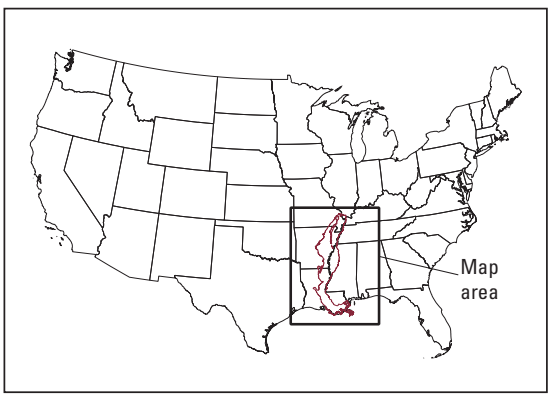

Figure 1. The extent of the Mississippi Alluvial Plain, the Mississippi River Valley alluvial aquifer, and the Mississippi Delta. 
Table 1. Characteristics of Aquaculture and Irrigation Water-Use Model (AIWUM) 1.0 and independent estimates of aquaculture and irrigation water use from models and datasets available in the Mississippi Alluvial Plain study area.

[--, not applicable]

\begin{tabular}{|c|c|c|c|c|c|}
\hline \multirow[b]{2}{*}{ Characteristic } & \multicolumn{5}{|c|}{ Model or dataset } \\
\hline & $\begin{array}{c}\text { Soil-Water-Balance code } \\
\text { (SWB) } 2.0 \\
\text { (Westenbroek and others, 2018) }\end{array}$ & $\begin{array}{l}\text { Mississippi Embayment } \\
\text { Regional Aquifer Study } \\
\text { (MERAS) } 2.0 \\
\text { (Clark and others, 2013) }\end{array}$ & $\begin{array}{c}\text { Mississippi Embayment } \\
\text { Regional Aquifer Study } \\
\text { (MERAS) } 2.1 \\
\text { (Haugh and others, 2019) }\end{array}$ & 5-year compilations & $\begin{array}{l}\text { Aquaculture and Irrigation } \\
\text { Water-Use Model } \\
\text { (AIWUM) } 1.0\end{array}$ \\
\hline Data requirements & $\begin{array}{l}\text { Soil hydrologic group, avail- } \\
\text { able water capacity, crop-type } \\
\text { distribution, surface-water } \\
\text { flow direction, climate, tables } \\
\text { of curve numbers, canopy } \\
\text { interception values, rooting } \\
\text { depths, and crop coefficients } \\
\text { for each crop type }\end{array}$ & $\begin{array}{l}\text { Areal recharge, water } \\
\text { withdrawal (mixture } \\
\text { of county-scale and } \\
\text { point data), water-level } \\
\text { observations, stream } \\
\text { network, hydraulic } \\
\text { properties }\end{array}$ & $\begin{array}{l}\text { Areal recharge, water } \\
\text { withdrawal (refined in } \\
\text { Mississippi Delta using } \\
\text { Yazoo Mississippi Delta } \\
\text { Joint Water Management } \\
\text { District data), water-level ob- } \\
\text { servations, stream network, } \\
\text { hydraulic properties }\end{array}$ & -- & $\begin{array}{l}\text { Crop-type distribution, } \\
\text { withdrawal rate (from } \\
\text { flowmeter data), irrigated } \\
\text { lands. }\end{array}$ \\
\hline Spatial resolution & 750 meters & 1 mile & 1 mile & County-level & $\begin{array}{l}\text { Variable ( } 1 \text { mile used in this } \\
\text { report to match MERAS } \\
\text { output). }\end{array}$ \\
\hline Temporal resolution & Daily & $\begin{array}{l}\text { Stress periods } 2 \text { through } \\
27(1870 \text { through } \\
\text { 1985): variable; } \\
\text { stress periods } 28 \\
\text { through } 69(1986 \\
\text { through 2007): } 6 \\
\text { months }\end{array}$ & $\begin{array}{l}\text { Stress periods } 2 \text { through } 27 \\
\text { (1870 through 1985): } \\
\text { variable; stress periods } 28 \\
\text { through } 84 \text { (1986 through } \\
\text { 2007): } 6 \text { months }\end{array}$ & 5 years & Monthly. \\
\hline Output & $\begin{array}{l}\text { Irrigation water use, evapotrans- } \\
\text { piration, runoff, recharge, } \\
\text { storage }\end{array}$ & $\begin{array}{l}\text { Water level, groundwater } \\
\text { withdrawal (using cell- } \\
\text { by-cell budget output) }\end{array}$ & $\begin{array}{l}\text { Water level, groundwater with- } \\
\text { drawal (using cell-by-cell } \\
\text { budget output) }\end{array}$ & $\begin{array}{l}\text { Water use (public supply, } \\
\text { irrigation, domestic, } \\
\text { livestock, aquaculture, } \\
\text { industrial, mining, ther- } \\
\text { moelectric power, and } \\
\text { hydroelectric power) }\end{array}$ & $\begin{array}{l}\text { Water use (aquaculture and } \\
\text { irrigation). }\end{array}$ \\
\hline Period covered & 2000 through 2014 & 1870 through 2007 & 1870 through 2014 & 1950 through 2015 & 1999 through 2017. \\
\hline
\end{tabular}


Table 1. Characteristics of Aquaculture and Irrigation Water-Use Model (AIWUM) 1.0 and independent estimates of aquaculture and irrigation water use from models and datasets available in the Mississippi Alluvial Plain study area.-Continued

$[--$, not applicable

\begin{tabular}{|c|c|c|c|c|c|}
\hline \multirow[b]{2}{*}{ Characteristic } & \multicolumn{5}{|c|}{ Model or dataset } \\
\hline & $\begin{array}{c}\text { Soil-Water-Balance code } \\
\text { (SWB) } 2.0 \\
\text { (Westenbroek and others, 2018) }\end{array}$ & $\begin{array}{c}\text { Mississippi Embayment } \\
\text { Regional Aquifer Study } \\
\text { (MERAS) } 2.0 \\
\text { (Clark and others, 2013) }\end{array}$ & $\begin{array}{l}\text { Mississippi Embayment } \\
\text { Regional Aquifer Study } \\
\text { (MERAS) } 2.1 \\
\text { (Haugh and others, 2019) }\end{array}$ & 5-year compilations & $\begin{array}{c}\text { Aquaculture and Irrigation } \\
\text { Water-Use Model } \\
\text { (AIWUM) } 1.0\end{array}$ \\
\hline Goal & $\begin{array}{l}\text { Quantification of water-budget } \\
\text { components }\end{array}$ & Simulation of water level & Simulation of water level & $\begin{array}{l}\text { National 5-year snapshots } \\
\text { of county-scale water use } \\
\text { for all major water-use } \\
\text { categories including } \\
\text { public supply, irriga- } \\
\text { tion, domestic, livestock, } \\
\text { aquaculture, industrial, } \\
\text { mining, thermoelectric } \\
\text { power, and hydroelectric } \\
\text { power }\end{array}$ & $\begin{array}{l}\text { Quantification of water } \\
\text { withdrawal for aqua- } \\
\text { culture and irrigation } \\
\text { purposes. }\end{array}$ \\
\hline Limitations & $\begin{array}{l}\text {-Uses literature values for crop- } \\
\text { coefficients, which determine } \\
\text { the amount of water required } \\
\text { for plants } \\
\text {-Assumes irrigators only } \\
\text { apply what crops need }\end{array}$ & $\begin{array}{l}\text {-Withdrawal reflects the } \\
\text { best-available water } \\
\text { withdrawal data at the } \\
\text { time the model was } \\
\text { developed }\end{array}$ & $\begin{array}{l}\text {-Withdrawal reflects the best- } \\
\text { available water withdrawal } \\
\text { data at the time the model } \\
\text { was developed }\end{array}$ & $\begin{array}{l}\text {-County-scale data is too } \\
\text { coarse for groundwater } \\
\text { models } \\
\text {-Only available once } \\
\text { every } 5 \text { years } \\
\text {-Based on variable and } \\
\text { unknown estimation } \\
\text { methods }\end{array}$ & $\begin{array}{l}\text {-See section in this report } \\
\text { titled "Strengths and } \\
\text { Weaknesses". }\end{array}$ \\
\hline
\end{tabular}




\section{Methods}

The general workflow of AIWUM 1.0 (fig. 2) consists of initialization of the model grid with a crop-type distribution; replacement of the crop type in each model cell with a withdrawal rate for that crop measured from flowmeter data for each monthly model time step (for example, April 2015); and removal of areas estimated as nonirrigated lands. Because the primary purpose of AIWUM 1.0 is to provide estimates of water withdrawal for aquaculture and irrigation purposes to the MERAS groundwater model, estimates are provided on a 1-mile (mi) grid for this study; however, a groundwater model is not required to run AIWUM 1.0. The only required input for AIWUM 1.0 is a geospatial raster (for example, GeoTIFF), a common component of groundwater models that defines the output extent, resolution, and projection system. Annual crop-type distributions were taken from the U.S. Department of Agriculture's (USDA's) gridded Cropland Data Layer (CDL) available as individual state or national datasets (U.S. Department of Agriculture, 2020). Crop-specific withdrawal rates within the Mississippi Delta were provided on an annual basis by the Mississippi Department of Environmental Quality (MDEQ) Delta Voluntary Metering Program (DVMP) as well as on a monthly and annual basis by the Yazoo Mississippi Delta Joint Water Management District (YMD; Powers, 2007; Massey and others, 2017). Average monthly irrigation frequencies were derived from the monthly flowmeter data from the YMD, and irrigated lands outside of the Mississippi Delta were determined using the Moderate Resolution Imaging Spectroradiometer (MODIS) Irrigated Agriculture Dataset for the United States (MIrAD-US; Brown and others, 2009; Pervez and Brown, 2010; Brown and Pervez, 2014) and determined inside the Mississippi Delta with permitted boundaries of irrigated lands provided by the MDEQ. Each component of the water-use calculation will be explained in more detail in following sections, but the general calculation at any given pixel located at $i, j$ and time $t$ is as follows:

$$
\begin{gathered}
q_{i, j, t, c}=\varphi r_{c, t} x y \theta_{t} \\
q_{i, j, t}=\sum_{c}^{n} q_{i, j, t, c}
\end{gathered}
$$

where:

$$
\begin{aligned}
& q_{i, j, t, c} \quad \text { is the water use at location } i, j \text { at time } t \text { for } \\
& \text { crop } c \text {, in cubic meters; } \\
& \varphi \quad \text { is the conversion factor from acre-feet per } \\
& \text { acre to cubic meters per square meter } \\
& \text { (3.28084); } \\
& r_{c, t} \quad \text { is the crop-specific withdrawal rates for crop } \\
& c \text {, in acre-feet per acre, at time } t \text {; } \\
& x \text { and } y \quad \text { are the pixel dimensions, in meters; } \\
& \theta_{t} \text { is the fraction of irrigated land for time } t \text {, in } \\
& \text { dimensionless units; and }
\end{aligned}
$$

$q_{i, j, t} \quad$ is the total irrigation water use for $n$ crops at location $i, j$ and time $t$, in cubic meters.

AIWUM 1.0 is capable of computing water use at two different spatial resolutions: 30 meter (m; the resolution of the CDL) or 10 times more refined than the model resolution ( $0.1 \mathrm{mi}$ for the MERAS model) and aggregates the estimates to the resolution of the raster provided to the model ( $1 \mathrm{mi}$ for the MAP region). These two computational resolutions allow for flexibility between accuracy and computational speed.

Because some input datasets for AIWUM 1.0 are available at a coarser resolution than $30 \mathrm{~m}$, computations at the $30-\mathrm{m}$ scale sometimes require resampling to a smaller spatial resolution (densifying a pixel into multiple pixels with the same value). For this report, a computational resolution of 10 times more refined than the model grid $(0.1 \mathrm{mi})$ was used to estimate irrigation water use in the MAP study area.

A versioning approach was taken in the development of AIWUM. Instead of focusing all efforts into constructing a single, final, static model requiring multiple years before a usable product is available, AIWUM development follows a versioning approach, with the release of revised models on an annual basis. The initial version (AIWUM 1.0) discussed in this report estimates aquaculture and irrigation water use as a function of crop type, crop-specific withdrawal rates, regional climate, and irrigated lands. Because AIWUM 1.0 estimates the amount of groundwater withdrawn from the underlying aquifer based on flowmeter data, the amount of water leaving the system via runoff, evapotranspiration, or recharge to the aquifer is not accounted for. Though acknowledging that agricultural water use is a function of other variables (for example, local climate, soil moisture, etc.) and certain parameters can be better constrained with additional data, this initial version is a substantial improvement on what is currently available for agricultural water-use estimates in the MAP.

Monthly and annual crop-specific withdrawal rates from the YMD used in AIWUM 1.0 along with monthly and annual rasters and estimated irrigation water use in the form of compressed Network Common Data Form (netCDF) files for the MAP study area are available at USGS ScienceBase (Wilson, 2021). The following sections will discuss each component of the water-use calculation in detail.

\section{Crop Type Designation}

The USDA's CDL was used to determine the crop-type distribution from 1999 through 2017 in the MAP study area. These crop-type classifications are available at a $30-\mathrm{m}$ resolution for the CONUS for 2008 through 2017 and at a 30- or 56-m resolution on a state-by-state basis for 1997 through 2007. Because crop-type data was not provided at the same resolution for all model years, some preprocessing was required for the CDL to be used in AIWUM 1.0. For years 1999 through 2007, when the CDL was available only on a state-by-state basis for most of the MAP study area, 56-m crop-type rasters were resampled to a $30-\mathrm{m}$ resolution using 


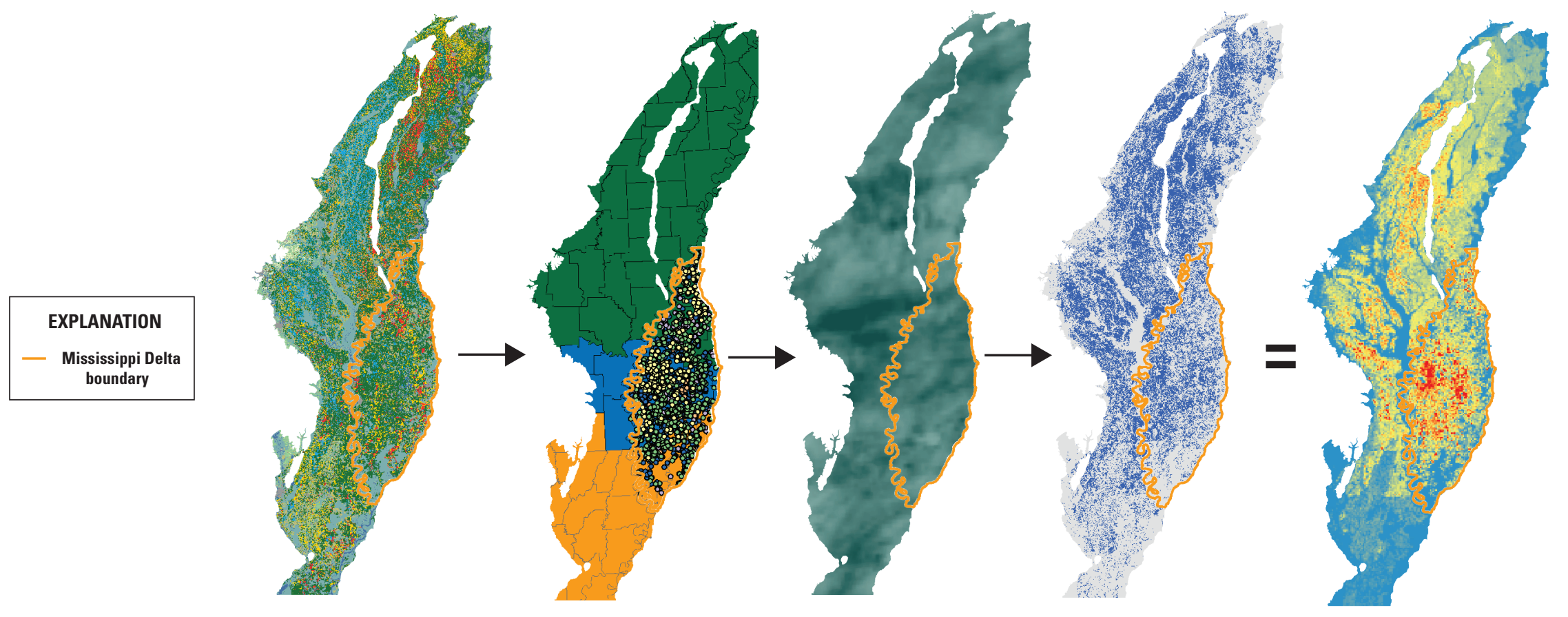

A

C

E

\section{Dataset description}

Source
Agricultural acres

$$
\begin{aligned}
& \text { U.S. Department of } \\
& \text { Agriculture }
\end{aligned}
$$

30 meters
Crop-specific irrigation rates

$$
\begin{gathered}
\text { Yazoo Mississippi Delta (YMD) } \\
\text { Joint Water Management District / } \\
\text { Mississippi Department of }
\end{gathered}
$$
Environmental Quality (MDEO)

\section{Climate (precipitation and} temperature)

$$
\begin{gathered}
\text { Parameter-Elevation } \\
\text { Regressions on } \\
\text { Independent Slopes Model } \\
\text { [PRISM] }
\end{gathered}
$$

800 meters
Irrigated lands

The Moderate Resolution Imaging Spectroradiometer (MODIS) Irrigated Agriculture Dataset for the United States (MlrAD-US)
250 meters

\section{Estimated aquaculture and irrigation water use}

Aquaculture and Irrigation Water-Use Mode (AIWUM)

Variable (1 mile in this report)

Temporal resolution

Monthly

2002, 2007, and 2012

Monthly

Figure 2. Depiction of the Aquaculture and Irrigation Water-Use Model (AIWUM) version 1.0 workflow. $A$ depicts the distribution of land use; $B$ shows the locations of Delta Voluntary Metering Program flowmeter data for aquaculture (orange), corn (green), cotton (purple), rice (yellow), and soybeans (blue) and the north, central, and south latitudinal zones in green, blue, and yellow, respectively; and $C, D$, and $E$ depict the distribution of climate data, irrigated lands, and estimated water use, respectively. 
GDAL's Warp function (GDAL contributors, 2019) and merged with 30-m crop-type rasters to produce annual crop-type rasters. The resulting datasets, in combination with 30-m CONUS-wide CDL datasets for years 2008 through 2017, were then resampled to the computational resolution $(0.1 \mathrm{mi})$ using GDAL's Warp function.

The beginning model period (1999) was selected based on the first availability of the CDL for Arkansas and Mississippi, which make up a majority of the study area (fig. 1). The CDL was not available until 2004 for Louisiana and was not available until 2008 for Kentucky and Tennessee; therefore, estimates for 1999-2008 cover a majority of the model study area but are incomplete for Louisiana for 1999-2003 and for Kentucky and Tennessee for 1999-2008. Agricultural water use in AIWUM 1.0 is assumed to be negligible for these regions for 1999-2008.

The misclassification of aquaculture as open water in the CDL is common in the MAP study area and needed to be addressed to more accurately estimate water use (Fowler and Rodekohr, 2015). To better delineate aquaculture, all pixels classified as "open-water" were reclassified as "aquaculture." Because this conversely results in a dataset with many pixels incorrectly classified as aquaculture (for example, rivers and natural ponds), the reclassified dataset was intersected with the waterbody ("NHDWaterbody") and area ("NHDArea") features from the USGS's National Hydrography Dataset (NHD) to correctly reclassify pixels over water features (U.S. Geological Survey, 2019b). Because some aquaculture is also identified in the NHDWaterbody dataset, all NHDWaterbody features with Fcode $=43601$ (aquaculture) were excluded, and the resulting polygon dataset was rasterized to the resolution of the model grid ( $0.1 \mathrm{mi})$ using GDAL.

\section{Crop-Specific Withdrawal Rate}

Aquaculture and irrigation withdrawal rates in the MAP study area are well-known compared to many other parts of the CONUS due in large part to efforts by the MDEQ and the YMD to measure monthly and annual withdrawal rates per acre at the withdrawal point, crops grown, and size of irrigated land associated with each flowmeter reading measured at each well. These monthly and annual rates are an integral part of estimating water use in the MAP study area and the surrounding region and were collectively used to develop monthly withdrawal rates for all modeled years as follows:

$r_{c, t}(m, y)=$

Annual YMD rates+Average YMD monthly distribution, Monthly YMD rates,

Annual YMD rates+Average YMD monthly distribution,

1999 less than and equal to $(\leq) y$ less than $(<) 2001$

$2002 \leq y<2010$

$2010 \leq y<2014$

Annual DVMP rates+Average YMD monthly distribution,

$y$ greater than and equal to $(\geq) 2014$

where

$r_{c, t}(m, y) \quad$ is the irrigation rate used for crop $c$ for month $m$ and year $y$ (see eq. 1).

Note that monthly or annual crop-specific withdrawal rates were not available for all modeled years and were estimated using methods described under the section "Monthly and Annual Crop-Specific Withdrawal Rates from the Yazoo Mississippi Delta Joint Water Management District."

Crop-specific withdrawal rates used in the model included rates derived from metered data on a monthly and annual basis by the MDEQ and the YMD for aquaculture, corn, cotton, rice, and soybeans. These crop-specific withdrawal rates measure withdrawal from groundwater, and the assumption is made that the entire withdrawal is applied to each field with minimal conveyance losses. The MDEQ dataset is composed of data collected within the Mississippi Delta from 2014 through 2017 from the DVMP, which reports agricultural water use from a volunteer network of flowmeters measured and reported annually by the irrigator at each flowmeter location. The benefit of this dataset lies within the spatial information associated with each flowmeter location that can be correlated with regional climate to derive climatic-dependent withdrawal rates with the working hypothesis that irrigators will use more water to irrigate crops when there is less rainfall and vice versa. The YMD dataset is composed of monthly data from 2002 through 2009, and annual data for 1999 through 2000, and 2010 through 2013 measured by YMD staff for all major crops within the Mississippi Delta. In contrast to the MDEQ flowmeter program, which uses flowmeters to report water use, the YMD measures the power consumption at each well and converts this power consumption to water use using the power-conversion-coefficient method (Massey and others, 2017). The benefit of the YMD dataset is its ability to characterize monthly water use for each major crop type, allowing AIWUM 1.0 to output monthly estimates of water use.

Sources of water can be groundwater or surface water, and different possible sources need to be considered when estimating water use. Because the goal of AIWUM is to estimate the amount of groundwater used for aquaculture and irrigation, it is important to restrict estimates to areas where solely groundwater is used; however, it is difficult to differentiate lands irrigated from groundwater from lands irrigated from surface water. Because a majority of agricultural water use in the study area likely 
comes from groundwater according to the 5-year compilations (U.S. Geological Survey, 2019a), the source of water was assumed to be groundwater for the entire study area. If AIWUM is applied in other areas outside of the MAP study area where surface water withdrawals make up a substantial proportion of water used for agricultural purposes, AIWUM would overestimate groundwater withdrawals.

\section{Annual Crop-Specific Withdrawal Rates from the Mississippi Department of Environmental Quality Delta Voluntary Metering Program}

Annual crop-specific withdrawal rate data and associated quality-assurance codes from 2014 through 2017 from the DVMP were provided by the MDEQ (Wilson, 2021). The reported data were filtered to ensure that the most representative data were included in AIWUM. Data with associated quality-assurance codes reported by the MDEQ were excluded from the final dataset for reasons including the following: incorrect units reported, irrigated other area, did not irrigate, multiple growing seasons, flowmeter installed after irrigation began, units not reported, no flowmeter installed, and metered partial growing season. The data were further screened by removing reported application rates within the dataset with unreasonably large (greater than [>] 10 acre-feet per acre for aquaculture; $>8$ acre-feet per acre for rice; and $>5$ acre-feet per acre for corn, cotton, and soybeans) and small ( $<0$ acrefeet per acre) crop-specific withdrawal rates as defined by the MDEQ (Mississippi Department of Environmental Quality, oral commun., 2018). Readings with no reported irrigated area were also removed. Additionally, withdrawal rates of 0 were excluded in the calculation of crop-specific withdrawal rates representative of irrigated areas with the assumption that the irrigated lands dataset should account for nonirrigated areas. Although conveyance losses could account for large withdrawal rates, they are assumed to be minimal in AIWUM 1.0. Because flowmeter locations were used in derivation of crop-specific withdrawal rates based on climate within spatial zones (herein termed "spatio-climatic withdrawal rates"), readings with missing coordinates were excluded. Because many fields are used to irrigate multiple crops within each season (double cropping), some crop-specific rates were complicated by double cropping. These rates were removed from the dataset by excluding data with more than one crop reported to prevent biasing the crop-specific withdrawal rates. Of the 7,089 total readings reported, 4,536 were used in AIWUM 1.0 (Wilson, 2021).

\section{Monthly and Annual Crop-Specific Withdrawal Rates from the Yazoo Mississippi Delta Joint Water Management District}

A total of 184 monthly and annual crop-specific withdrawal rates from the YMD were used to estimate aquaculture and irrigation water use. Monthly rates for each meter were summed annually and used in addition to annual rates to quality-assure each annual rate according to the same criteria as the DVMP data. None of the 184 monthly crop-specific withdrawal rates reported by YMD were filtered based on the quality-assurance criteria; however, because annual cropspecific withdrawal rates were not available from the YMD for 2001, and several annual crop-specific withdrawal rates provided by the YMD with associated small sample sizes appeared to be outliers when plotted against total precipitation, weighted-simple-linear regression was used to estimate rates for all crops for 2001 and specific crops for years identified as outliers. Weighted-simple-linear regression was used instead of ordinary-simple-linear regression to allow annual average crop-specific withdrawal rates with higher certainty (less spread in individual rates) to have higher influence on the regression model. The general regression equation for each crop was as follows:

$$
r=\beta_{0}+\beta_{1} * P_{\text {median }}+\varepsilon
$$

where

$$
\begin{aligned}
r & \text { is the crop-specific withdrawal rates, } \\
\beta_{0} \text { and } \beta_{1} & \text { are coefficients, } \\
P_{\text {median }} & \text { is the median precipitation, and } \\
\varepsilon & \text { is the error term. }
\end{aligned}
$$

The median precipitation value was determined based on the median estimated precipitation value from January through September at all MDEQ flowmeter locations. Although it would be ideal to use precipitation data at the locations of the flowmeters used to calculate the annual YMD crop-specific withdrawal rates, those locations are not available. Because aquaculture is irrigated year-round, the median precipitation used in the aquaculture regression model was determined using precipitation data from January through December of each year. Precipitation at each flowmeter location was estimated using monthly, gridded, $800-\mathrm{m}$ precipitation data from the PRISM Climate Group (Daly and others, 1994). Several crop-specific withdrawal rates with small sample sizes (6 to 35) plotted far from the general pattern of the data and were replaced with predicted values from the regression model. Prediction, which takes place within AIWUM 1.0, is carried out using the StatsModels module in Python (Seabold and Perktold, 2010). 


\section{Distribution of Monthly Crop-Specific Withdrawal Rates}

To incorporate the annual DVMP and YMD crop-specific withdrawal rates into AIWUM 1.0, the annual rates needed to be distributed into monthly rates. Based on YMD monthly crop-specific withdrawal rates from 2002 through 2009 (fig. 3), an average percentage of total water use (for example, 30 percent applied in April, 40 percent applied in May, etc.) was derived for each crop. For years 1999 through 2001 and 2010 through 2017 when annual crop-specific withdrawal rates were used, each monthly rate was determined by multiplying the annual rate by the corresponding normalized percentage $\left(\alpha_{c, m}\right.$, see eq. 5). Each percentage was calculated by averaging all the monthly crop-specific withdrawal rates from YMD from 2002 through 2009 for each crop (see eq. 7 and fig. 3) and normalizing by the total water use (see eq. 6), resulting in the percentage of total use withdrawn in each month.

$$
\begin{gathered}
r_{c, t}=r_{c}(y) \alpha_{c, m} \\
\alpha_{c, m}=\frac{r_{\text {avg }, c, m}}{\sum_{m=4}^{10} r_{a v g, c, m}} \\
r_{\text {avg }, c, m}=\frac{\sum_{y=20802}^{200} r_{y, m}}{n}
\end{gathered}
$$

where

$$
\begin{aligned}
& r_{c, t} \quad \text { is the crop-specific withdrawal rates used in } \\
& \text { AIWUM } 1.0 \text { for crop } c \text { at time } t \text { (see eq.1), } \\
& r_{c}(y) \quad \text { is the crop-specific withdrawal rates from the } \\
& \text { DVMP dataset for crop } c \text { for year } y \text {, } \\
& a_{c, m} \quad \text { is the percentage for crop } c \text { and month } m \text {, } \\
& r_{\text {avg, }, m} \text { is the average crop-specific withdrawal rates } \\
& \text { for crop } c \text { and month } m \text {, } \\
& r_{y, m} \quad \text { is the crop-specific withdrawal rates for crop } \\
& c \text { from year } y \text { and month } m \text { from the YMD } \\
& \text { dataset, and } \\
& n \quad \text { is the number of years of YMD data } \\
& \text { for } \operatorname{crop} c \text {. }
\end{aligned}
$$

\section{Spatio-Climatic Withdrawal Rates}

Because the amount of water used for aquaculture and irrigation is likely a function of precipitation and regional practices, spatio-climatic withdrawal rates were developed to compartmentalize crop-specific withdrawal rates within the MAP study area into six different zones based on latitude and precipitation. For years where geolocated flowmeter data were available (2014 through 2017 from the DVMP dataset), spatio-climatic zones were delineated from flowmeters within the Mississippi Delta and used to apply crop-specific withdrawal rates across the greater MAP study area (fig. 4). Latitudinal zones were delineated according to the following criteria in an effort to generally approximate regional differences in irrigation practices and weather patterns: the north region was delineated by the union of all counties with centroids north of Tallahatchie County, Mississippi; the south region was delineated by the union of all counties south of Holmes County, Miss.; and the central region was delineated by the union of all other counties. Precipitation zones within each latitudinal zone were delineated based on the median estimated precipitation value during the growing season (April through September) at all flowmeter locations (32 inches for 2014, 21 inches for 2015, 22 inches for 2016, and 30 inches for 2017). Precipitation at each flowmeter location was estimated using monthly $800-\mathrm{m}$ precipitation data from the PRISM Climate Group (Daly and others, 1994). Crop-specific withdrawal rates were derived for 2014 through 2017 within each of the six spatio-climatic zones and used in AIWUM 1.0 (table 2).

\section{Irrigated Lands}

Currently (2021) little data is available on the distribution of irrigated lands, especially at a temporal and spatial resolution required for many groundwater, watershed, and water budget models. The primary sources of gridded irrigated-lands data are a 1-kilometer raster dataset from Falcone and LaMotte (2016) available for 1950, 1954, 1959, 1964, 1969, 1974, 1978, 1982, 1987, 1992, 1997, 2002, 2007, and 2012 and the USGS's MIrAD-US available at a 250-m resolution for 2002, 2007, and 2012 (Brown and others, 2009; Pervez and Brown, 2010; Brown and Pervez, 2014). The Falcone and LaMotte (2016) dataset consists of county-scale irrigation data from the USDA's Census of Agriculture merged with the National Land Cover Database agricultural land cover (Falcone, 2015) and evenly allocates the number of irrigated acres reported in the Census of Agriculture surveys to the areas mapped as cropland in each county. The MIrAD-US uses a similar approach to Falcone and LaMotte (2016), but uses the annual peak normalized difference vegetation index from the National Aeronautics and Space Administration (NASA)'s Moderate Resolution Imaging Spectroradiometer (MODIS) imagery to attempt to separate irrigated and nonirrigated cropland spatially at a 250-m resolution (Brown and others, 2009; Pervez and Brown, 2010; Brown and Pervez, 2014) rather than assign a constant percentage of irrigation for all cropland pixels in a county. The MIrAD-US dataset was selected for use in AIWUM 1.0 model because of its spatial resolution and assumed higher accuracy.

The values from the MIrAD-US dataset were first resampled from the 250-m resolution to the computational resolution using the GDAL_NearestNeighbor resampling algorithm then used to set $\theta_{t}$ in eq. 1 at each pixel, thereby clipping water use. This masking process was applied to cotton, corn, and soybeans but not aquaculture or rice, which were assumed to always require water. Because the MIrAD-US dataset is not 
A. Aquaculture
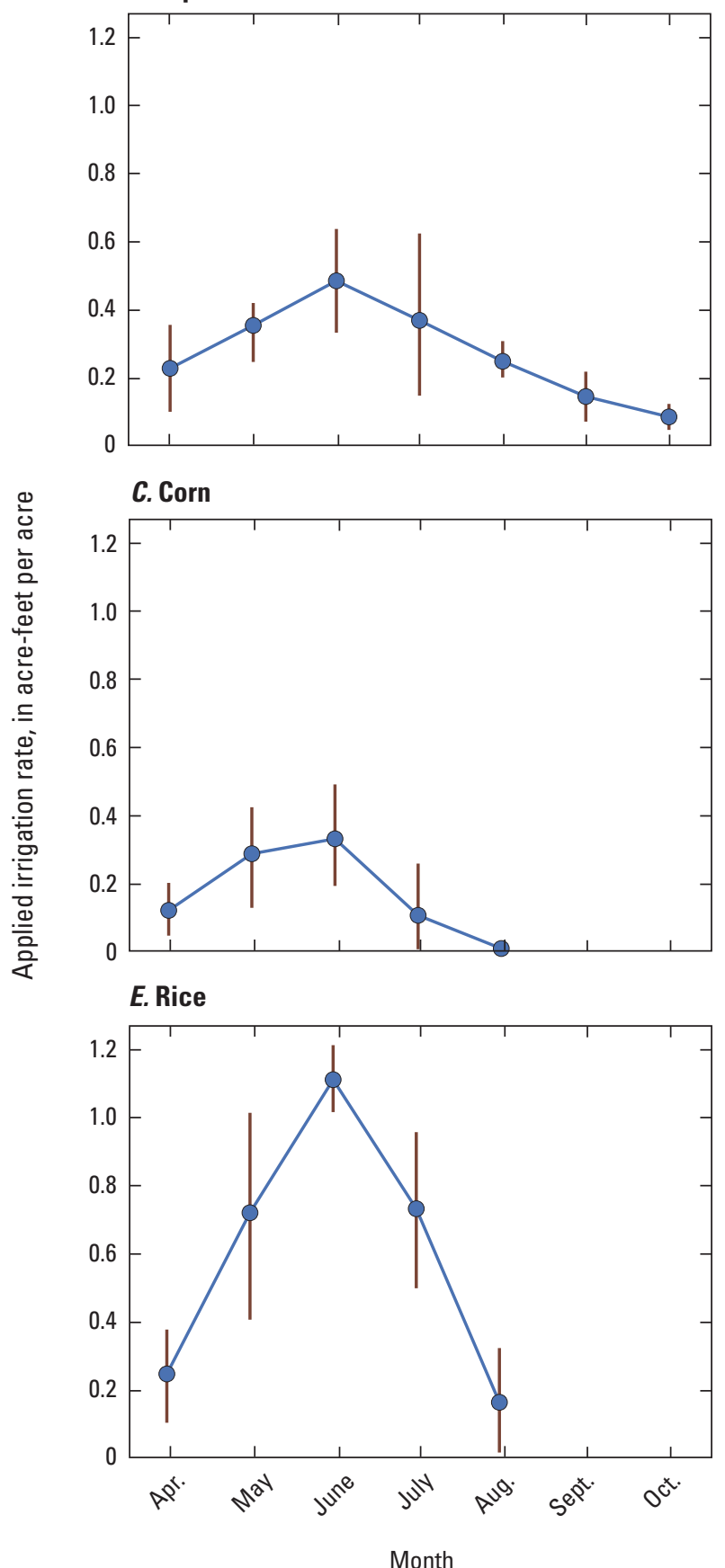

\section{B. Cotton}

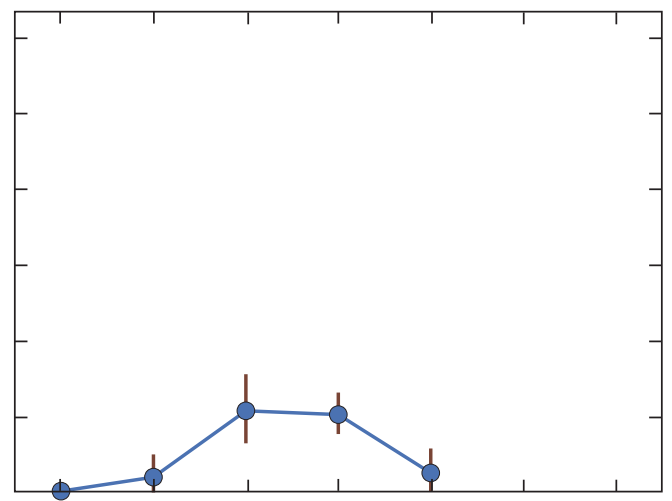

D. Soybeans

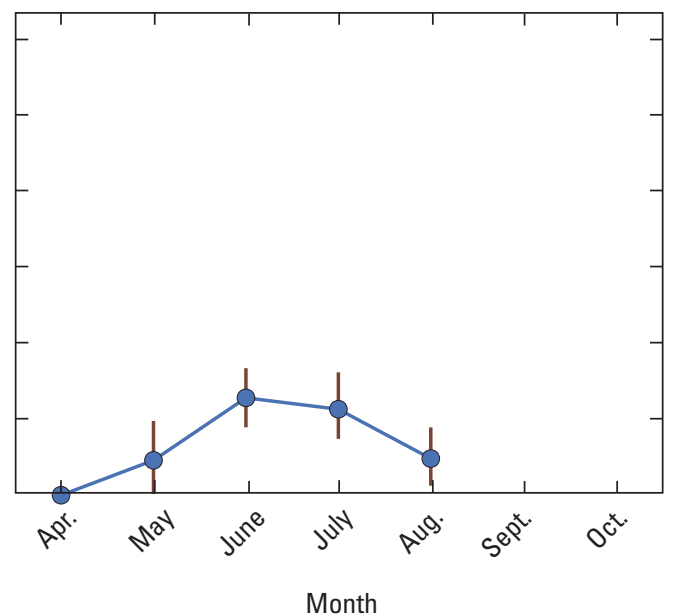

EXPLANATION

- Applied irrigation rate

Upper limit of standard deviation

Average

Lower limit of standard deviation

Figure 3. Monthly crop-specific withdrawal rates from Yazoo Mississippi Delta Joint Water Management District data, 2002 through 2009. The lines and error bars indicate the average and standard deviation of the irrigation rate for each month. 


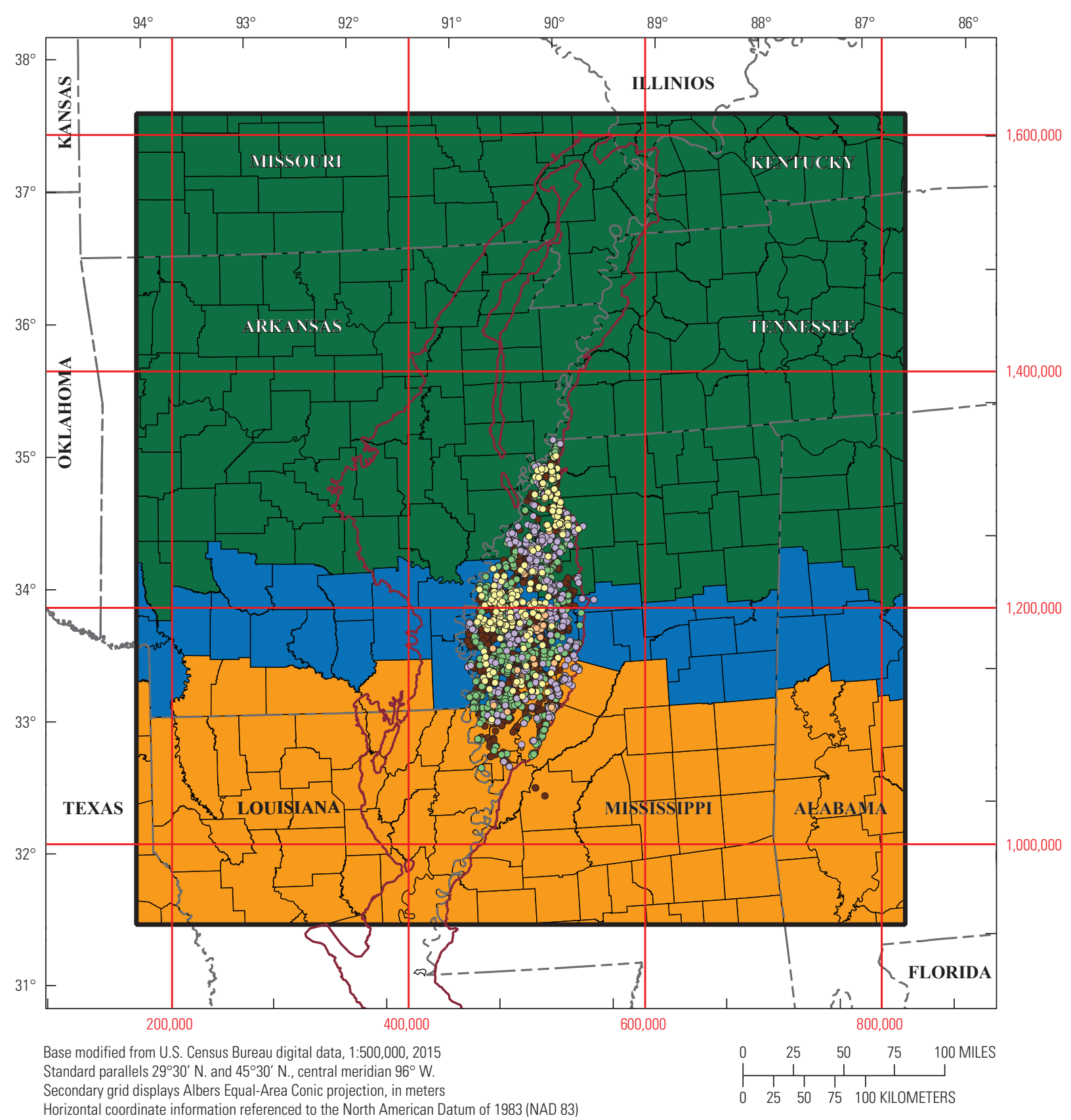

Horizontal coordinate information referenced to the North American Datum of 1983 (NAD 83)

\section{EXPLANATION}

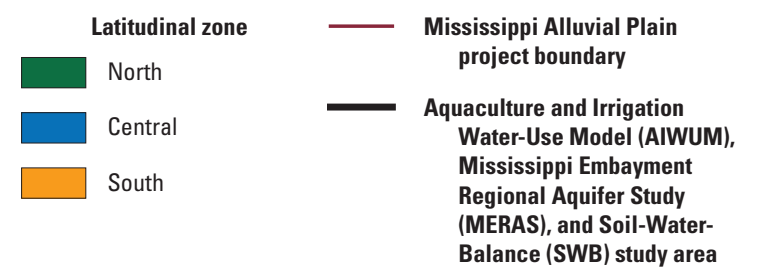
Crop type at flowmeter location
- Aquaculture
- Corn
- Cotton
- Rice
- Soybeans

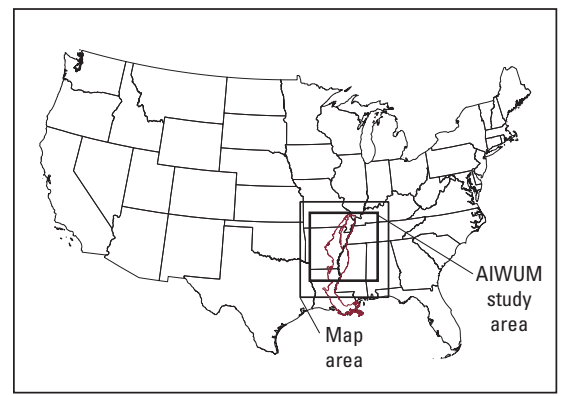

Figure 4. Spatio-climatic zones and flowmeter locations and type within the Mississippi Delta and the Mississippi Alluvial Plain study area, 2015. 
Table 2. Annual crop-specific withdrawal rates, in acre-feet per acre, within each spatio-climatic zone, 2014 through 2017. Precipitation zones were derived based on the median precipitation delivered from April to September at all Mississippi Department of Environmental Quality Delta Voluntary Metering Program flowmeter locations within each latitudinal zone for each year.

$[<$, less than; $\geq$, greater than or equal to $]$

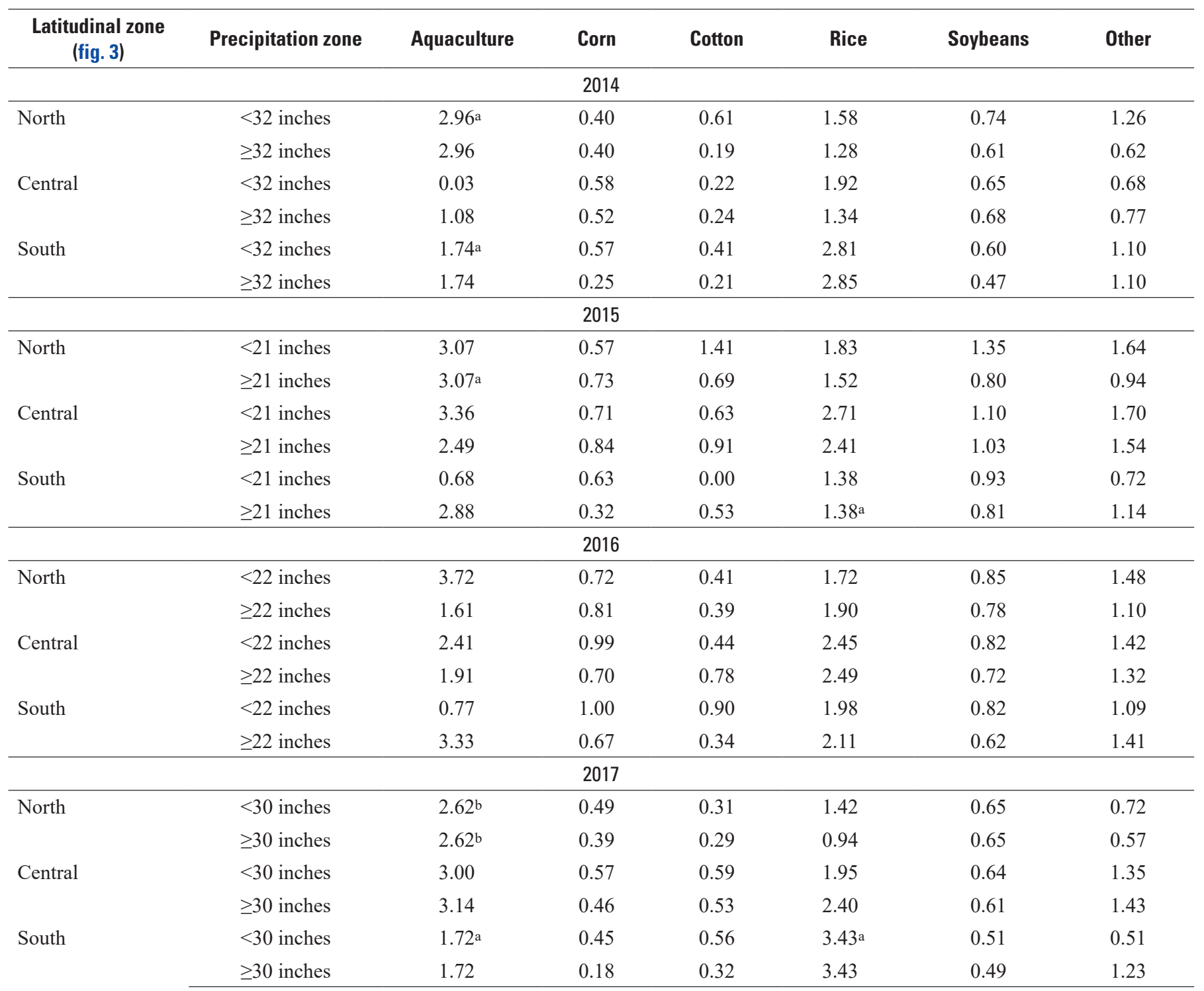

aNo reported values available in zone; average value for crop and region used.

bNo reported values available in region; average value for crop used.

available for every year, each modeled year was matched with the closest year available in the MIrAD-US dataset, rounding up when necessary.

Although there are limited data available for irrigated lands for the CONUS, regional datasets are available in some areas. In the Mississippi Delta, the MDEQ maintains a database of all lands with permits to withdrawal groundwater for aquaculture and irrigation purposes. Although it is likely that not all withdrawal is included in this database, it likely covers a majority of all irrigated lands in the Mississippi
Delta. This database of permitted boundaries was used to clip water-use estimates within the Mississippi Delta by rasterizing the permitted boundaries dataset for 1999 through 2017 to the computational resolution $(0.1 \mathrm{mi})$ and clipping out water use outside the permitted boundaries $\left(\theta_{t}\right.$ in eq. 1 set to 1 within permitted boundaries and 0 outside permitted boundaries). 


\section{Comparisons of Estimates with Other Models}

To determine the accuracy of AIWUM 1.0 at estimating water use in the MAP study area, ideally independent metered data would be used to validate estimates from AIWUM 1.0; however, because little metered data are available and those data are used in development of crop-specific withdrawal rates used in AIWUM 1.0, comparisons were made to reported aquaculture and irrigation water-use data and independent water-use and groundwater models. Comparisons were made with the reported water-use data for 2005, 2010, and 2015 and with independent water-use estimates from models for a common, representative modeled year, 2006. In each comparison the percent difference (PD) was calculated between the two datasets during the growing season as follows:

$$
\text { percent difference (PD) }=\frac{\left(q_{\mathrm{R}, i, j, t}-q_{\mathrm{AIWuM}, i, j, t}\right)}{\left(q_{\mathrm{R}, i, j, t}\right)} \times 100 \%
$$

where

$$
\begin{array}{rc}
q_{R, i, j, t} & \begin{array}{c}
\text { is the reference water-use estimate at location } \\
i, j \text { and time } t \text {, and }
\end{array} \\
q_{A I W U M, i, j, t} & \begin{array}{c}
\text { is AIWUM water-use estimate at location } i, j \\
\text { and time } t .
\end{array}
\end{array}
$$

The median PD was calculated for each common time step to evaluate differences over time. Because a majority of the study area contained locations without water use, medians were only calculated between datasets at locations where either dataset had an estimated water use greater than 0 to avoid a bias about 0 .

\section{U.S. Geological Survey 5-Year Water-Use Compilations}

The USGS's National Water-Use Science Project is responsible for compiling and publishing water-use estimates for the United States. These compilations, which have been conducted since 1950, are published on a 5-year cycle with county-level data available since 1985 (U.S. Geological Survey, 2020). Water use is separated into water-use categories including public supply, irrigation, domestic, livestock, aquaculture, industrial, mining, thermoelectric power, and hydroelectric power.

Comparisons were made between estimates from AIWUM 1.0 and county-scale aquaculture and irrigation water-use estimates compiled by the USGS for 2005, 2010, and 2015 (U.S. Geological Survey, 2019a). Because the methodologies used in estimating the aquaculture and irrigation water-use data in each 5-year compilation varies state-by-state from recording site-specific water use, to using crop coefficients, to direct estimation, these data have an unquantified amount of error but serve as a general benchmark for probable water use. Aquaculture and irrigation water use in the 5-year compilations is separated by source (surface water or groundwater); therefore, aquaculture and irrigation water use from groundwater were summed and used in comparisons.

Water-use totals from AIWUM 1.0 and the 5-year compilations were joined to county polygons for 2005, 2010, and 2015 (U.S. Census Bureau, 2017).

\section{Soil-Water-Balance 2.0}

SWB 2.0 is a model developed to estimate spatial and temporal variations in groundwater recharge using a modified Thornthwaite-Mather soil-water-balance approach, which estimates components of the SWB on a daily timestep (Westenbroek and others, 2018). One estimated component in SWB 2.0 is crop irrigation demand, which is calculated based on the methodology presented in Food and Agriculture Organization (FAO)-56 (Allen and others, 1998). Comparing estimates from AIWUM 1.0 with SWB 2.0 allows not only for another independent assessment of spatial variability of water-use estimates but a better temporal comparison as well.

Crop irrigation estimates from SWB 2.0 for the MAP study area from January 1, 2000, to December 31, 2014, are available as a USGS data release in the format of a NetCDF file (Westenbroek and others, 2021). To compare the monthly water-use estimates from AIWUM 1.0 with the daily crop irrigation demand estimates from SWB 2.0, estimates from SWB 2.0 were aggregated to a monthly timestep using the xarray package in Python (Hoyer and Hamman, 2017).

\section{Mississippi Embayment Regional Aquifer Study Groundwater Models}

In 2009, a regional groundwater flow model was constructed as part of the MERAS to assess water availability in the Mississippi embayment (Clark and Hart, 2009). The model, which spanned from 1870 to 2007 and consisted of 414 rows, 397 columns, and 13 layers covering 78,000 square miles, was constructed using MODFLOW-2005. In 2013, additional changes to the MERAS groundwater model were made to improve the model in Arkansas, including modification of water-use estimates used in MERAS 1.0, to produce MERAS 2.0, which used a county-wide, average water-use value estimated every 5 years (Clark and others, 2013) that were applied at a constant water-use rate during the entire growing season.

In a collaborative effort between the USGS and the MDEQ to assess proposed alternative water-supply scenarios and their effect on future water availability in the Mississippi Delta, the original MERAS model was updated and enhanced in the Mississippi Delta with water-use, precipitation, and recharge data through 2013 (Haugh and others, 2019). The county-wide, average water use every 5 years in MERAS 2.0 was refined in MERAS 2.1 to estimates on the scale of the model grid (1 $\mathrm{mi}$ by $1 \mathrm{mi}$ ) on a seasonal basis using water-use estimates provided by the YMD. For each MERAS model 
version (MERAS 2.0 and 2.1), the model was run and the cell-by-cell budget (the water withdrawal from each cell) was calculated for each time step. Withdrawals from wells were then extracted from the cell-by-cell budget file using the FloPy Python package (Bakker and others, 2016). Both MERAS 2.0 and 2.1 are available in a USGS data release (Haugh, 2019).

To compare irrigation water-use estimates from AIWUM 1.0 to each MERAS model, output estimates from AIWUM 1.0 were resampled to a daily timestep using the pandas package in Python (McKinney, 2010). The average daily water use from AIWUM 1.0 was then calculated for all days within each MERAS model stress period, and comparisons were then made for each stress period coinciding with the first and second halves within the growing season (April through June and July through September, respectively) and the first and second halves outside the growing season (October through December and January through March, respectively).

\section{Aquaculture and Irrigation Water-Use in the Mississippi Alluvial Plain, 1999-2017}

Correction of crop-specific withdrawal rates was possible because of the negative linear relation between the crop-specific withdrawal rates and the median total precipitation at MDEQ flowmeter locations, supporting the working hypothesis that withdrawal rates increase with a decrease in precipitation. Through interrogation of outliers in the annual crop-specific withdrawal rate data from YMD, the following rates were replaced with predicted values from the regression models: soybeans for 1999, 2000, and 2013; cotton for 2010; and corn for 2013 (table 3).

Total aquaculture and irrigation water-use estimates in the study area ranged from 5.42 billion gallons per day in 2017 to 13.1 billion gallons per day in 2010 (table 3). For 2015, total water use was 2.72 trillion gallons (table 3; fig. 5). Figures 6 through 11 show the spatial extent of water use for aquaculture and irrigated crops. On average, rice accounted for a majority of water use in the MAP with about 1.6 trillion gallons (about 51 percent of total water use) over 1.7 million acres (about 24 percent of total irrigated area; table 4), followed by soybeans with about 0.8 trillion gallons (about 26 percent of total water use) over 3.1 million acres (about 44 percent of total irrigated area; table 4). All other uses each account for less than 10 percent of total water use. Spatially, areas with more intense, localized water use driven by rice irrigation and aquaculture are located within the central portion of the Mississippi Delta and the southeastern portion of Arkansas (fig. 5). Temporally, total water use generally decreased for rice and generally increased for soybeans during the model period (table 4).

The method used in this study to estimate the distribution of aquaculture water use in the study area did well at classifying aquaculture where it is present. Before reclassification of aquaculture, an average of 90 thousand acres from 1999 through 2017 were classified as aquaculture, and an average of 296 thousand acres were calculated after reclassification. Small differences between the alignment of pixels classified as "open water" or "water" in the CDL with the rasterized NHD resulted in small aquaculture water use artifacts in the study area (fig. 6); however, these inaccuracies in water use were small (about $<0.03$ acre-feet per acre), composing about 2 percent of the total aquaculture water use and about 0.2 percent of overall total water use, and had little effect on the general spatial distribution of water use in the MAP study area.

\section{Comparison to USGS 5-Year Water-Use Compilations}

Annual total water use from the 5-year compilations ranged from 3.4 trillion gallons ( 9.6 billion gallons per day) in 2000 to 4.6 trillion gallons (12.6 billion gallons per day) in 2015 (fig. 12). Comparison between aquaculture and irrigation water use from AIWUM 1.0 and USGS 5-year water-use compilations for 2005, 2010, and 2015 indicated that wateruse estimates and irrigated area from AIWUM 1.0 in Arkansas and Mississippi within the MAP boundary were generally smaller with PDs for 2005, 2010, and 2015 typically greater than 0 (fig. 13). AIWUM 1.0 tended to estimate larger water use than the 5-year compilations outside the MAP boundary where USDA CDL data were available. The annual total water use from the 5-year compilations appears to gradually increase; whereas, estimates from other methods (AIWUM 1.0, MERAS 2.0, MERAS 2.1, and SMB 2.0) have much more variation (fig. 12). 
Table 3. Median precipitation values, annual applied withdrawal rates, and total estimated water use for each model year for the Mississippi Alluvial Plain study area, 1999 through 2017.

[MDEQ, Mississippi Department of Environmental Quality; T2, see table 2 in this report]

\begin{tabular}{|c|c|c|c|c|c|c|c|c|c|c|c|c|}
\hline \multirow[b]{2}{*}{ Year } & \multirow{2}{*}{$\begin{array}{c}\text { Median total } \\
\text { precipitation at } \\
\text { MDEQ Voluntary } \\
\text { Metering Network } \\
\text { locations, January } \\
\text { through September, } \\
\text { in inches }\end{array}$} & \multirow{2}{*}{$\begin{array}{c}\text { Median total } \\
\text { precipitation at } \\
\text { MDEQ Voluntary } \\
\text { Metering } \\
\text { Network } \\
\text { locations, } \\
\text { January through } \\
\text { December, in } \\
\text { inches }\end{array}$} & \multicolumn{6}{|c|}{ Applied irrigation rate, in acre-feet per acre } & \multirow[b]{2}{*}{$\begin{array}{c}\text { Irrigated } \\
\text { area, in } \\
\text { thousands } \\
\text { of acres }\end{array}$} & \multicolumn{3}{|c|}{ Estimated total irrigation water use } \\
\hline & & & Aquaculture & Corn & Cotton & Rice & Soybeans & Other & & Cubic meters & $\begin{array}{l}\text { Trillions } \\
\text { of gallons }\end{array}$ & $\begin{array}{c}\text { Billions of gallons } \\
\text { per day }\end{array}$ \\
\hline 1999 & 35.2 & 46.0 & $2.87 \mathrm{a}$ & 0.90 & 0.60 & 3.30 & $0.77 \mathrm{~b}$ & 1.69 & 7,468 & $1.20 \mathrm{E}+10$ & 3.17 & 8.67 \\
\hline 2000 & 30.7 & 48.9 & $2.62^{\mathrm{a}}$ & 1.20 & 0.70 & 3.60 & $0.91^{\mathrm{b}}$ & 1.80 & 7,468 & $1.10 \mathrm{E}+10$ & 2.92 & 8.00 \\
\hline 2001 & 32.9 & 67.7 & $1.08^{\mathrm{a}}$ & $0.85^{\mathrm{a}}$ & $0.57 \mathrm{a}$ & $2.79 \mathrm{a}$ & $0.84 \mathrm{a}$ & 1.23 & 7,468 & $9.92 \mathrm{E}+09$ & 2.62 & 7.18 \\
\hline 2002 & 36.4 & 66.2 & $1.20^{\mathrm{a}}$ & 0.93 & 0.55 & 3.15 & 0.68 & 1.30 & 7,468 & $1.13 \mathrm{E}+10$ & 2.98 & 8.16 \\
\hline 2003 & 32.1 & 51.9 & $2.37 \mathrm{a}$ & 0.58 & 0.47 & 2.83 & 0.64 & 1.38 & 7,468 & $8.64 \mathrm{E}+09$ & 2.28 & 6.25 \\
\hline 2004 & 38.6 & 63.9 & 1.45 & 0.42 & 0.34 & 2.50 & 0.37 & 1.02 & 7,468 & $7.68 \mathrm{E}+09$ & 2.03 & 5.56 \\
\hline 2005 & 26.1 & 42.0 & $3.19^{a}$ & 0.96 & 0.51 & 2.96 & 0.60 & 1.65 & 7,847 & $1.33 \mathrm{E}+10$ & 3.52 & 9.65 \\
\hline 2006 & 29.7 & 53.8 & 1.85 & 1.16 & 0.84 & 3.34 & 1.00 & 1.64 & 7,847 & $1.32 \mathrm{E}+10$ & 3.50 & 9.58 \\
\hline 2007 & 26.4 & 42.9 & 1.98 & 0.82 & 0.52 & 2.97 & 0.77 & 1.41 & 7,847 & $1.09 \mathrm{E}+10$ & 2.88 & 7.88 \\
\hline 2008 & 31.3 & 60.4 & 1.37 & 1.25 & 0.62 & 3.08 & 1.00 & 1.46 & 7,847 & $1.42 \mathrm{E}+10$ & 3.74 & 10.3 \\
\hline 2009 & 37.9 & 71.0 & $0.81^{\mathrm{a}}$ & 0.91 & 0.27 & 2.79 & 0.62 & 1.08 & 7,847 & $1.08 \mathrm{E}+10$ & 2.85 & 7.81 \\
\hline 2010 & 25.0 & 37.0 & $3.60^{\mathrm{a}}$ & 0.82 & $0.73^{b}$ & 3.53 & 1.14 & 1.96 & 7,937 & $1.80 \mathrm{E}+10$ & 4.77 & 13.1 \\
\hline 2011 & 25.6 & 47.9 & $2.71^{\mathrm{a}}$ & 1.32 & 0.71 & 3.78 & 1.14 & 1.93 & 7,937 & $1.63 \mathrm{E}+10$ & 4.30 & 11.8 \\
\hline 2012 & 27.6 & 49.5 & $2.58^{\mathrm{a}}$ & 0.90 & 0.86 & 3.61 & 1.18 & 1.83 & 7,937 & $1.59 \mathrm{E}+10$ & 4.19 & 11.5 \\
\hline 2013 & 40.7 & 62.4 & $1.51^{\mathrm{a}}$ & $0.67 \mathrm{~b}$ & $0.42^{\mathrm{a}}$ & 3.03 & $0.61^{b}$ & 1.25 & 7,937 & $1.04 \mathrm{E}+10$ & 2.74 & 7.51 \\
\hline 2014 & 37.9 & 58.2 & $\mathrm{~T} 2$ & $\mathrm{~T} 2$ & $\mathrm{~T} 2$ & $\mathrm{~T} 2$ & $\mathrm{~T} 2$ & $\mathrm{~T} 2$ & 7,937 & $9.27 \mathrm{E}+09$ & 2.45 & 6.71 \\
\hline 2015 & 35.6 & 57.8 & $\mathrm{~T} 2$ & $\mathrm{~T} 2$ & $\mathrm{~T} 2$ & $\mathrm{~T} 2$ & $\mathrm{~T} 2$ & $\mathrm{~T} 2$ & 7,937 & $1.03 \mathrm{E}+10$ & 2.72 & 7.45 \\
\hline 2016 & 39.8 & 55.3 & $\mathrm{~T} 2$ & $\mathrm{~T} 2$ & $\mathrm{~T} 2$ & $\mathrm{~T} 2$ & $\mathrm{~T} 2$ & $\mathrm{~T} 2$ & 7,937 & $1.07 \mathrm{E}+10$ & 2.83 & 7.77 \\
\hline 2017 & 32.1 & 51.9 & $\mathrm{~T} 2$ & $\mathrm{~T} 2$ & $\mathrm{~T} 2$ & $\mathrm{~T} 2$ & $\mathrm{~T} 2$ & $\mathrm{~T} 2$ & 7,937 & $7.48 \mathrm{E}+09$ & 1.98 & 5.42 \\
\hline
\end{tabular}

aMissing value was predicted using regression.

bValue predicted using regression because the original value was an outlier. 


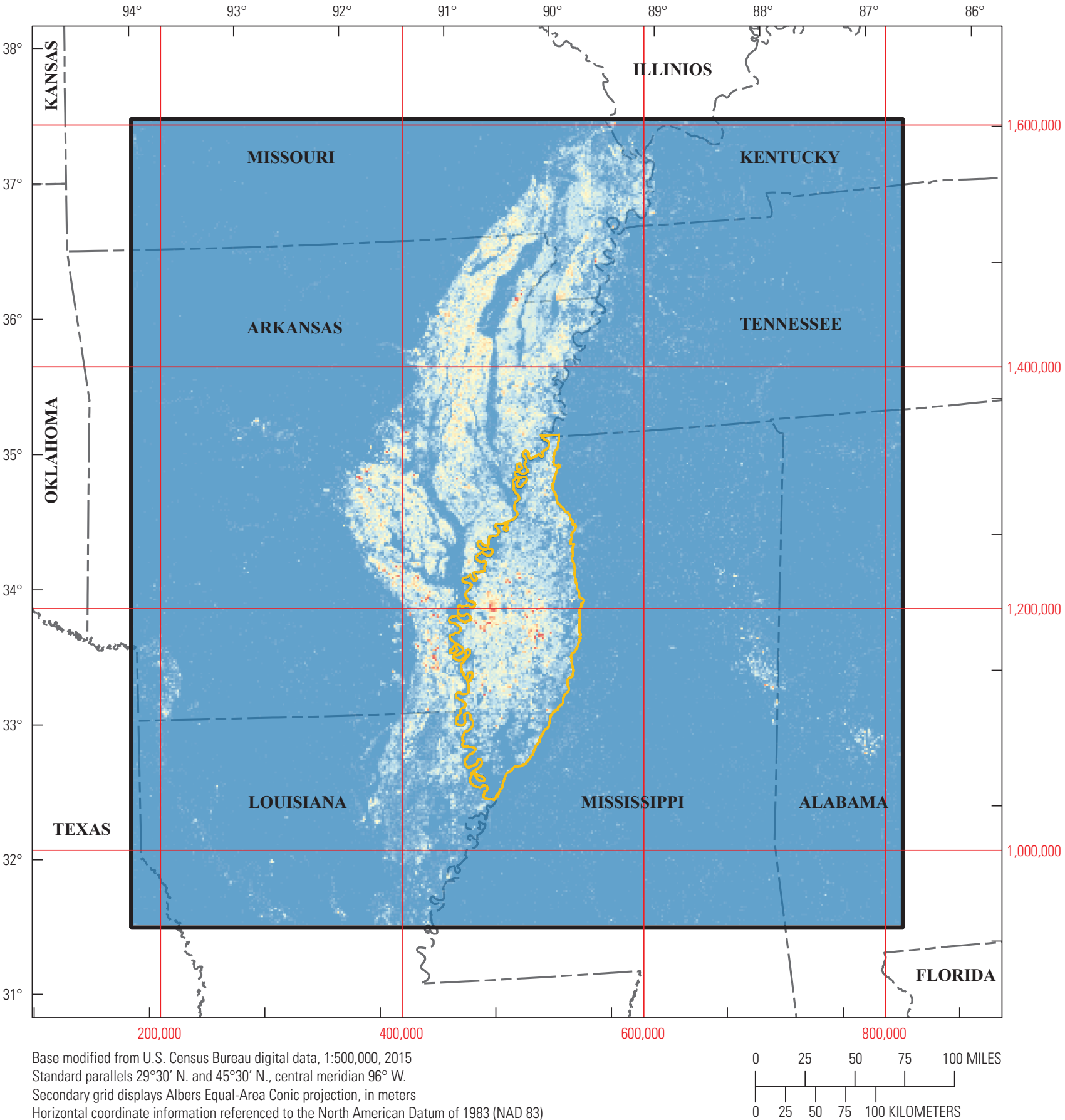

EXPLANATION

Total aquaculture and irrigation water use, in acre-feet per acre

0

0.1 to 0.5

0.6 to 1.0

1.1 to 1.5

1.6 to 2.6
Aquaculture and Irrigation Water-Use Model (AIWUM), Mississippi Embayment Regional Aquifer Study (MERAS), and Soil-WaterBalance (SWB) study area

Mississippi Delta boundary

Figure 5. Estimated total aquaculture and irrigation water use for the Mississippi Alluvial Plain study area, 2015. 


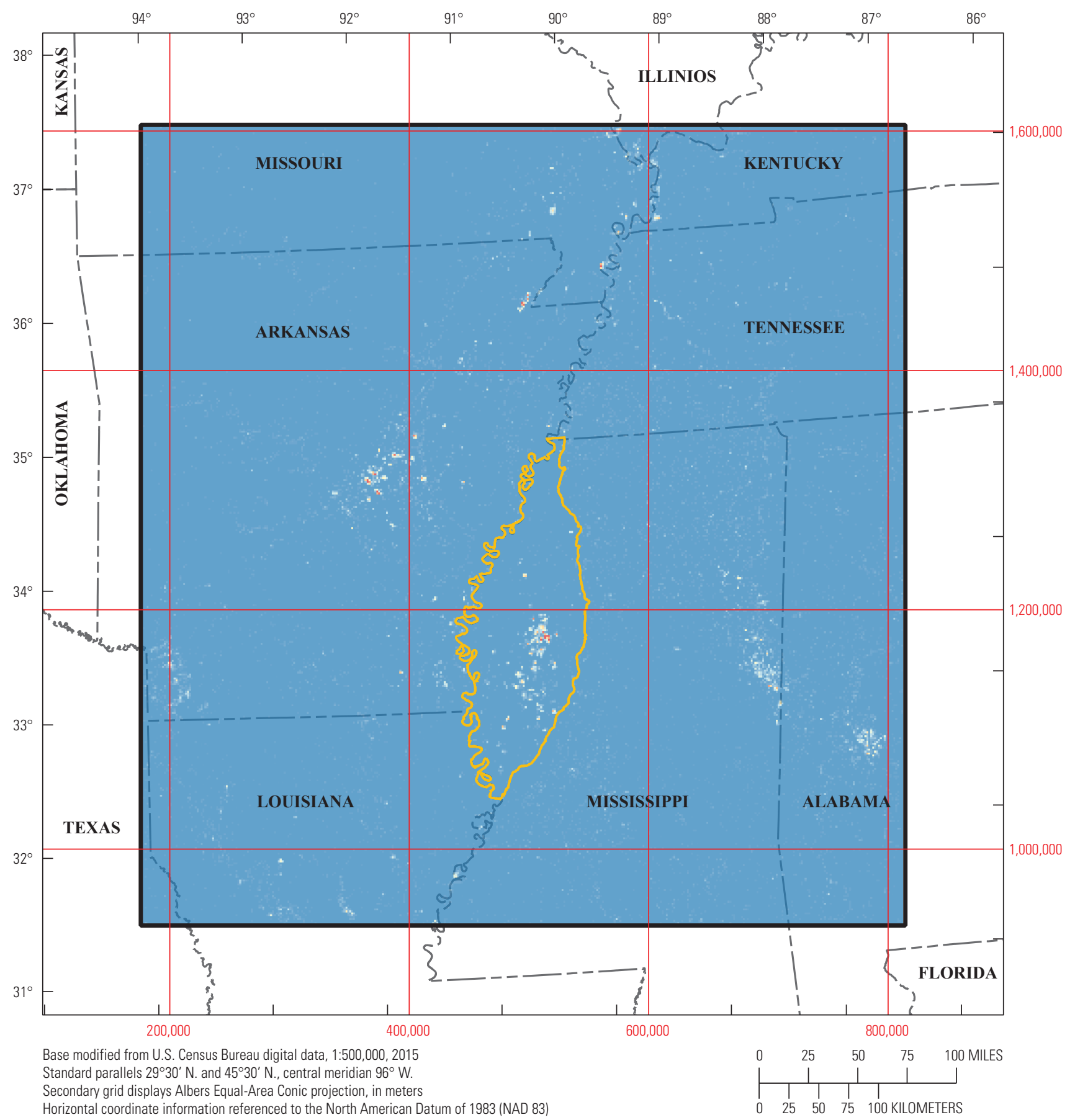

\section{EXPLANATION}
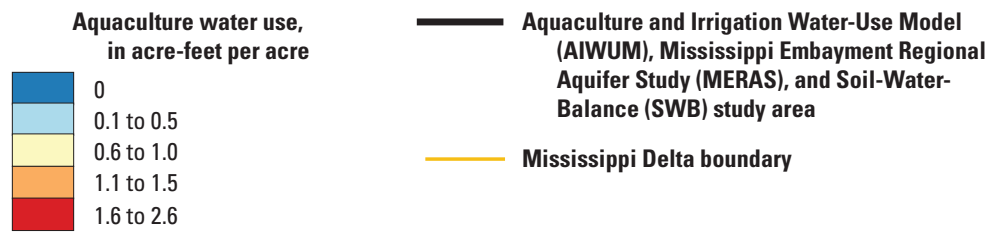

Figure 6. Estimated water use for aquaculture for the Mississippi Alluvial Plain study area, 2015. 


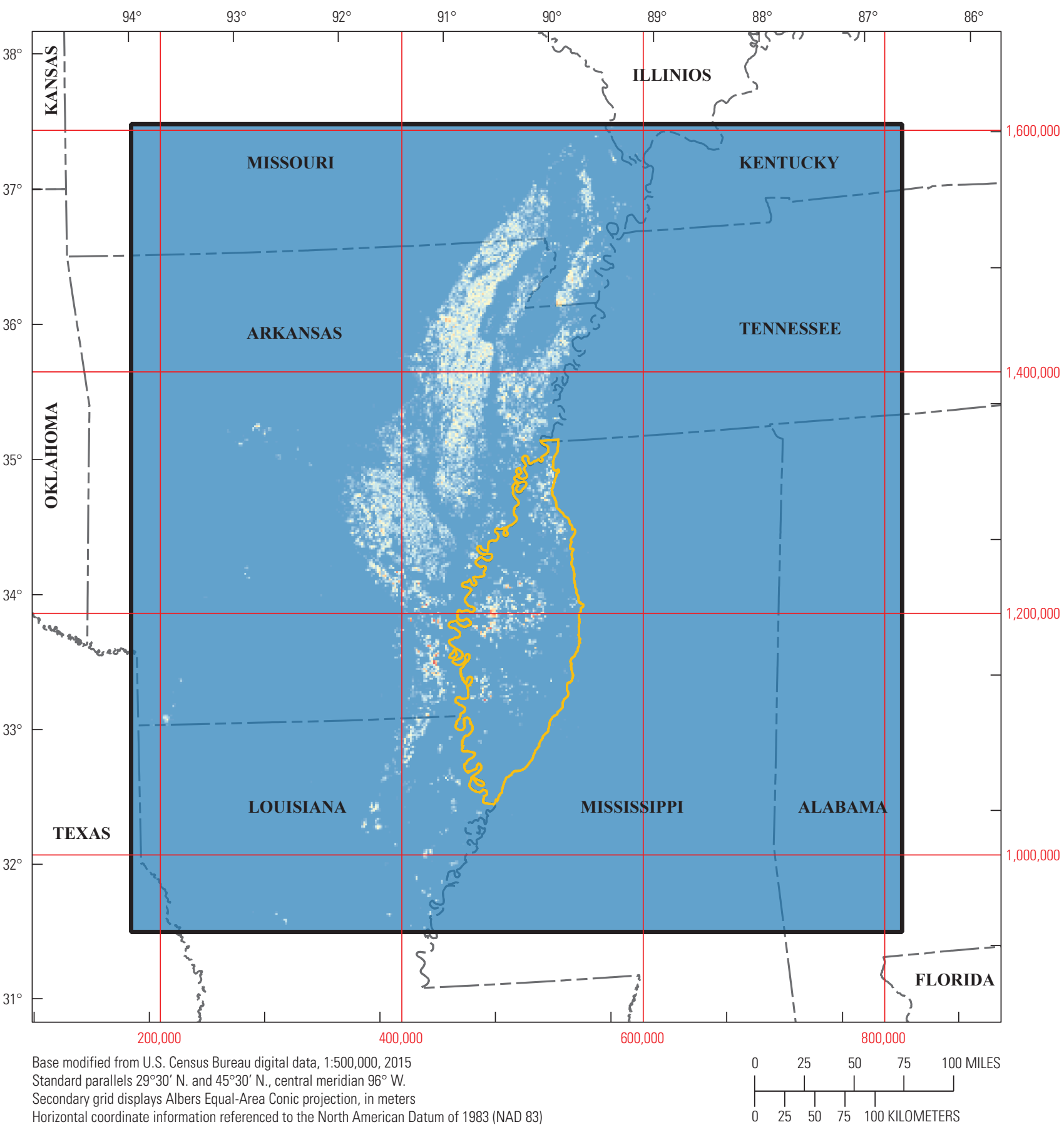

\section{EXPLANATION}
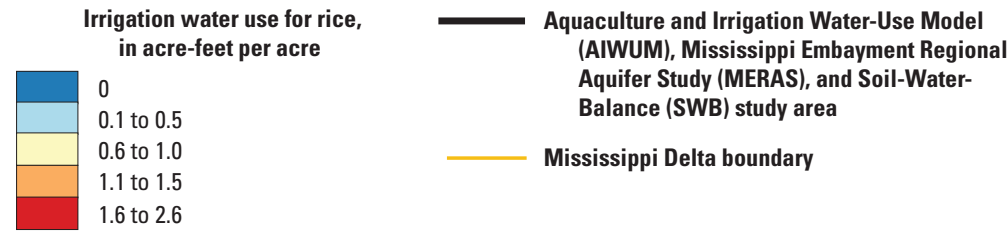

(AIWUM), Mississippi Embayment Regiona

Balance (SWB) study area

- Mississippi Delta boundary

Figure 7. Estimated water use for rice for the Mississippi Alluvial Plain study area, 2015. 


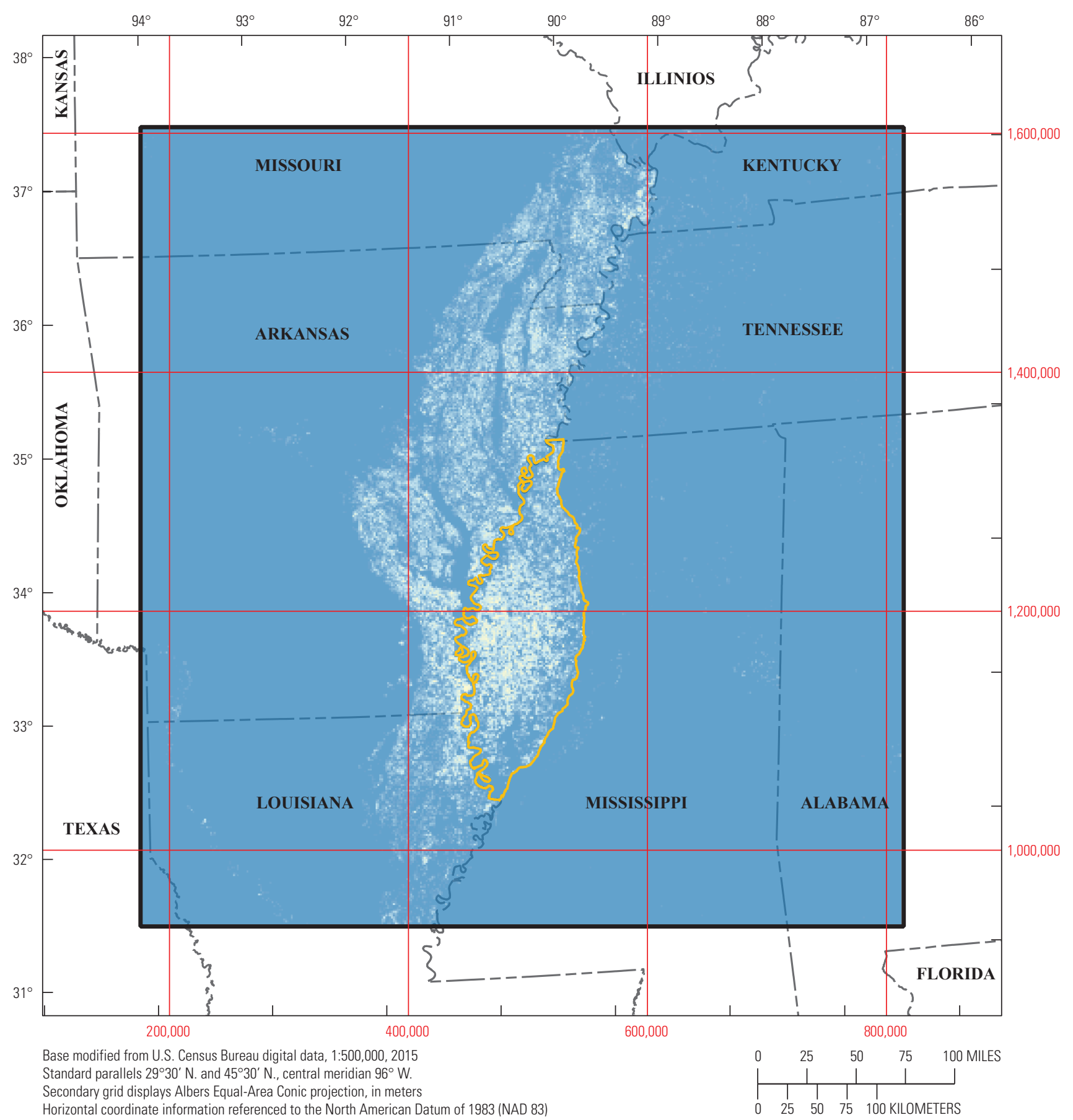

EXPLANATION

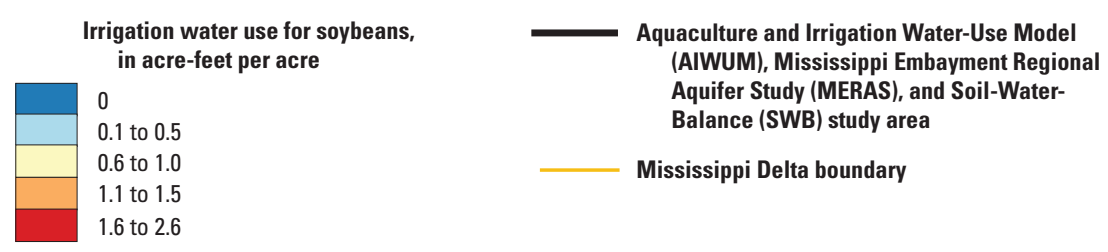

Figure 8. Estimated water use for soybeans for the Mississippi Alluvial Plain study area, 2015. 


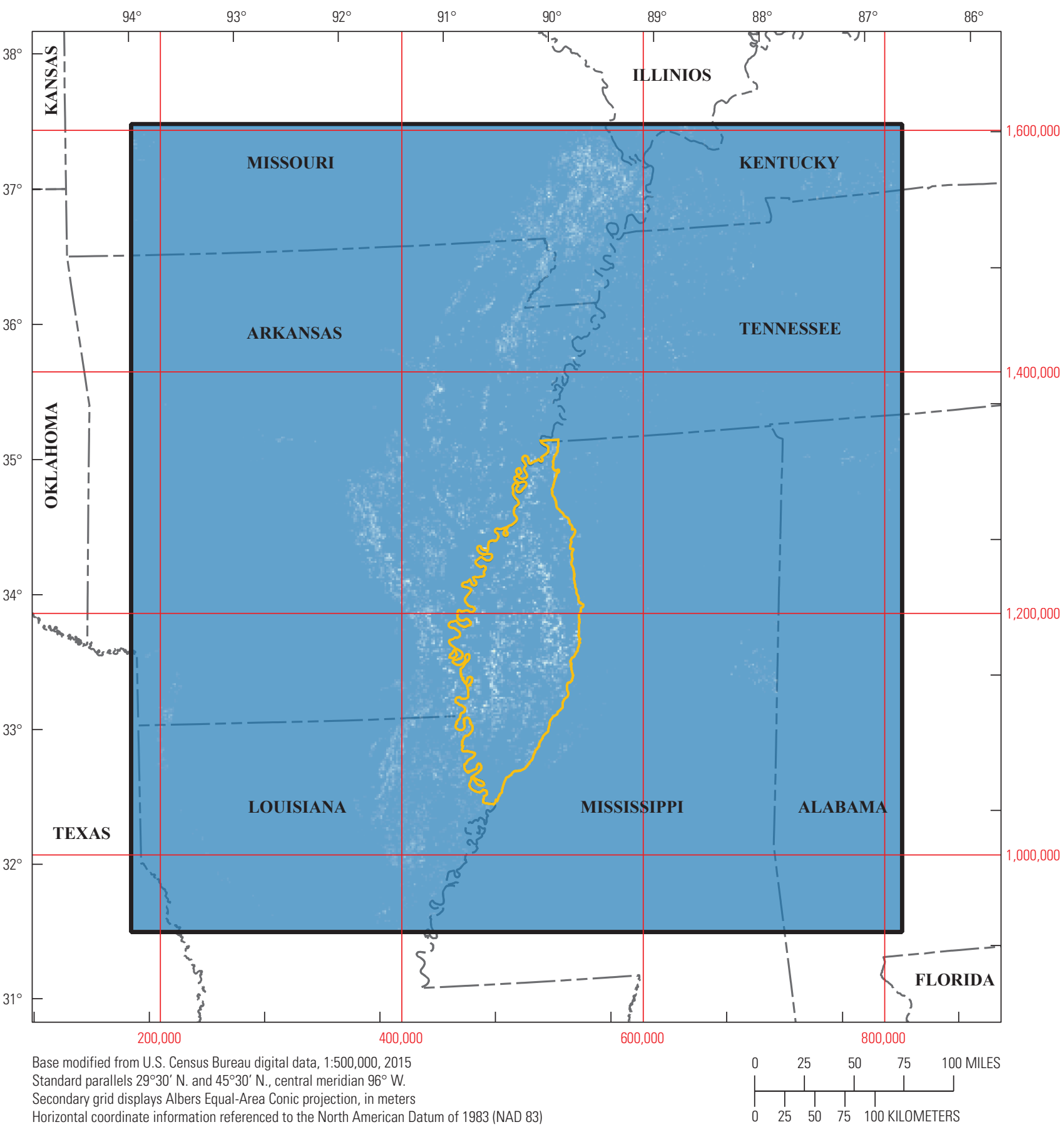

\section{EXPLANATION}
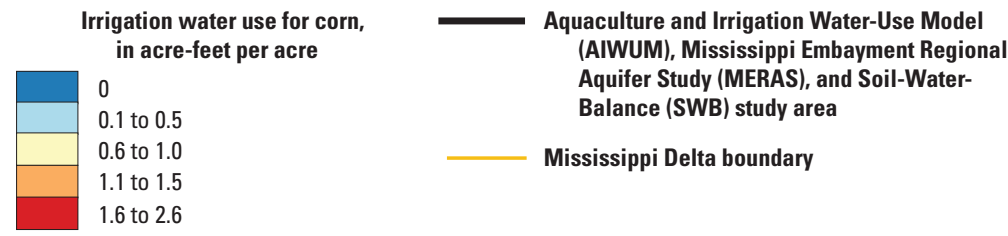

(AIWUM), Mississippi Embayment Regiona

Balance (SWB) study area

Mississippi Delta boundary

Figure 9. Estimated water use for corn for the Mississippi Alluvial Plain study area, 2015. 


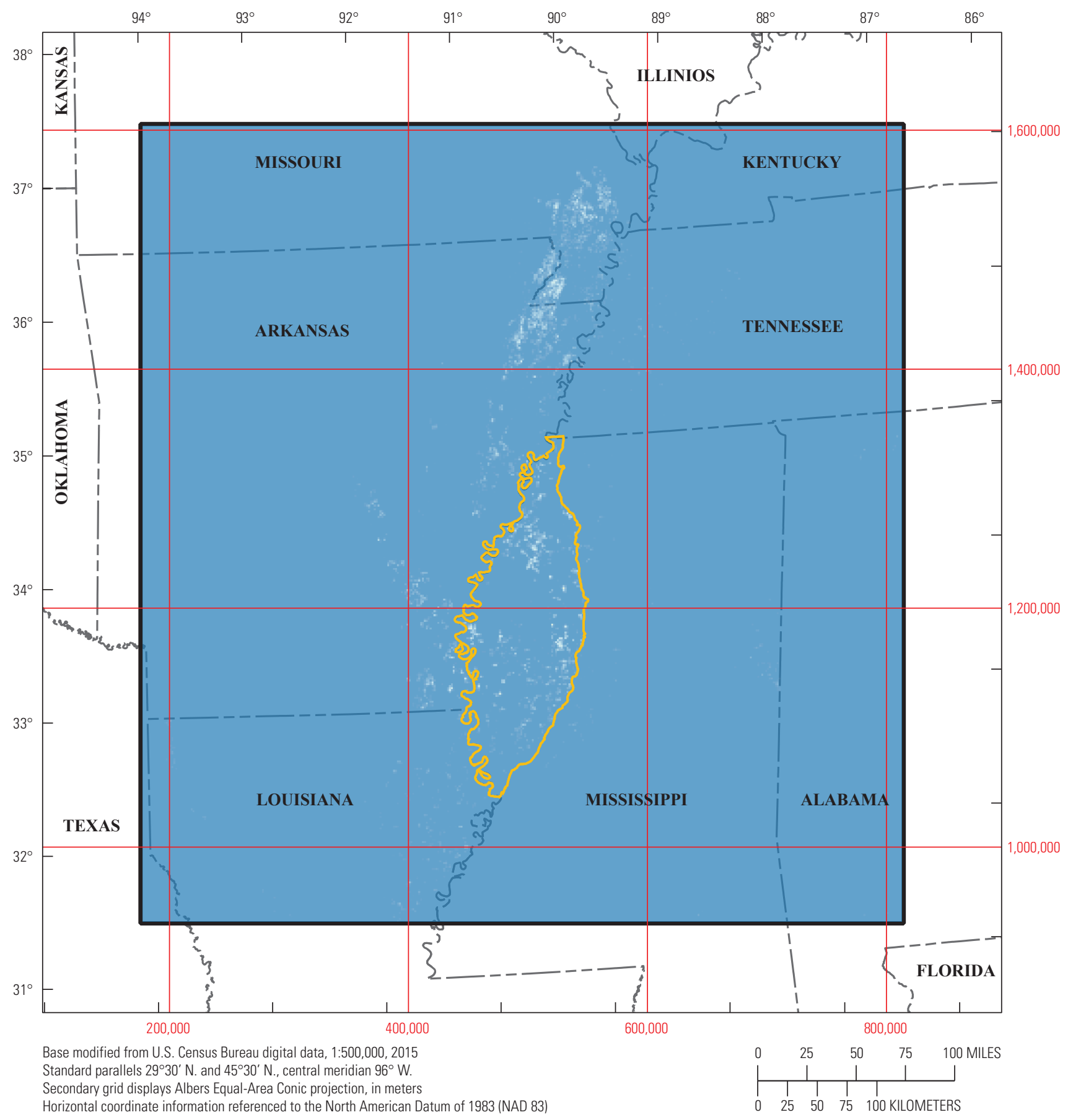

\section{EXPLANATION}

Irrigation water use for cotton, in acre-feet per acre

0.1 to 0.5

0.6 to 1.0

1.1 to 1.5

1.6 to 2.6

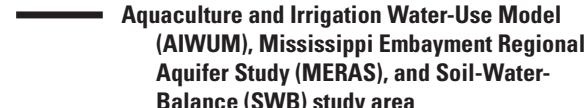

Balance (SWB) study area

Mississippi Delta boundary

Figure 10. Estimated water use for cotton for the Mississippi Alluvial Plain study area, 2015. 


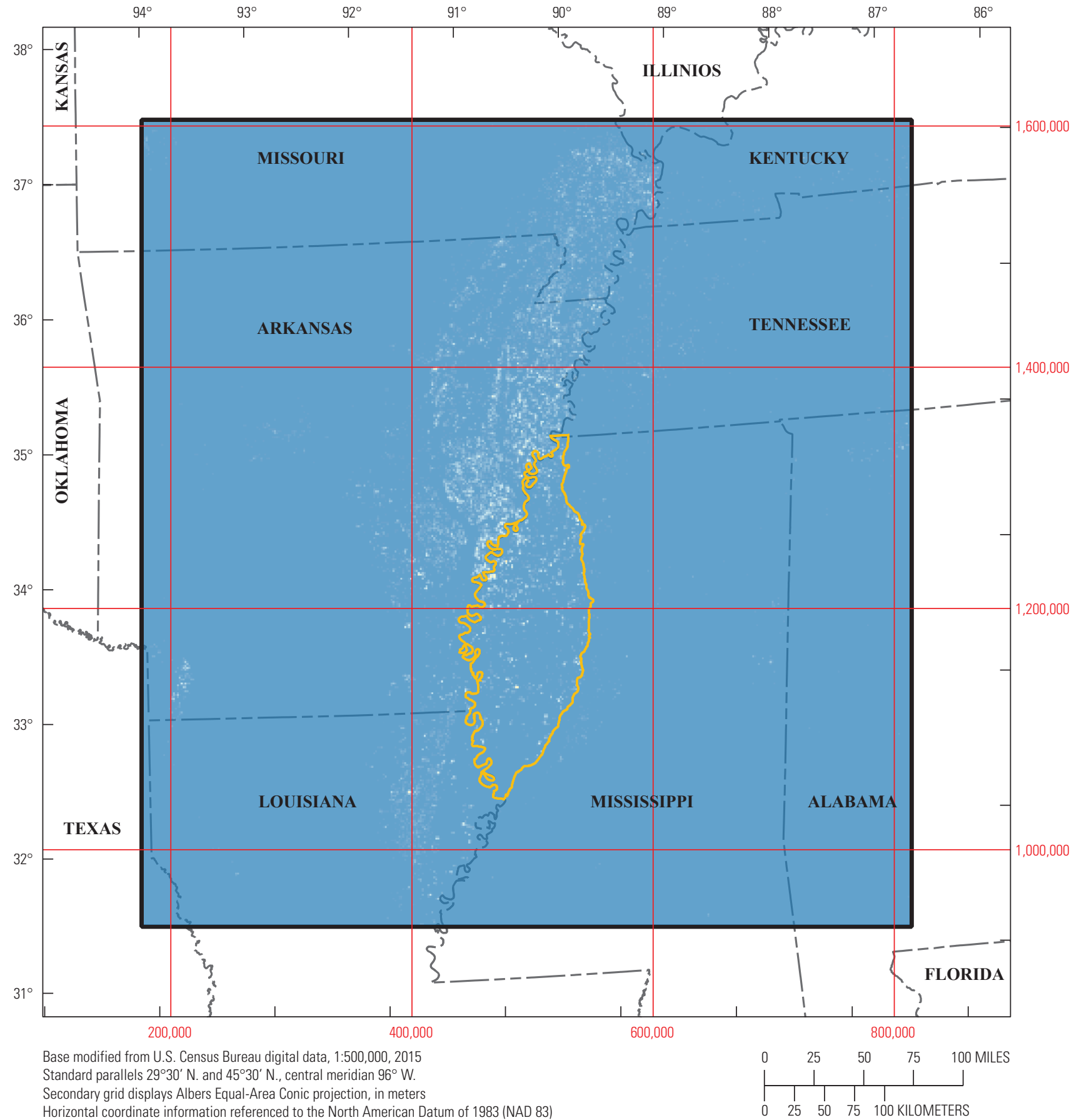

\section{EXPLANATION}

Irrigation water use for all crops other than rice, soybeans, corn, and cotton, in acre-feet per acre

\section{0}

0.1 to 0.5

0.6 to 1.0

1.1 to 1.5

1.6 to 2.6
Aquaculture and Irrigation Water-Use Model (AIWUM), Mississippi Embayment Regional Aquifer Study (MERAS), and Soil-WaterBalance (SWB) study area

Mississippi Delta boundary

Figure 11. Estimated water use for all other crops for the Mississippi Alluvial Plain study area, 2015. 
Table 4. Annual total area and water use and annual percentage of total crop area and water use for aquaculture, corn, cotton, other crops, rice, and soybeans in the Mississippi Alluvial Plain, 1999 through 2017.

\begin{tabular}{|c|c|c|c|c|c|c|c|c|c|c|c|c|}
\hline \multirow[b]{2}{*}{ Year } & \multicolumn{4}{|c|}{ Aquaculture } & \multicolumn{4}{|c|}{ Corn } & \multicolumn{4}{|c|}{ Cotton } \\
\hline & $\begin{array}{l}\text { Total } \\
\text { area, in } \\
\text { thousands } \\
\text { of acres }\end{array}$ & $\begin{array}{c}\text { Percent } \\
\text { of total } \\
\text { crop } \\
\text { area }\end{array}$ & $\begin{array}{c}\text { Total } \\
\text { water } \\
\text { use, in } \\
\text { billions } \\
\text { of } \\
\text { gallons }\end{array}$ & $\begin{array}{c}\text { Percent } \\
\text { of total } \\
\text { water } \\
\text { use }\end{array}$ & $\begin{array}{l}\text { Total } \\
\text { area, in } \\
\text { thousands } \\
\text { of acres }\end{array}$ & $\begin{array}{c}\text { Percent } \\
\text { of total } \\
\text { crop } \\
\text { area }\end{array}$ & $\begin{array}{c}\text { Total } \\
\text { water } \\
\text { use, in } \\
\text { billions } \\
\text { of } \\
\text { gallons }\end{array}$ & $\begin{array}{c}\text { Percent } \\
\text { of total } \\
\text { water } \\
\text { use }\end{array}$ & $\begin{array}{c}\text { Total } \\
\text { area, in } \\
\text { thousands } \\
\text { of acres }\end{array}$ & $\begin{array}{c}\text { Percent } \\
\text { of total } \\
\text { crop } \\
\text { area }\end{array}$ & $\begin{array}{c}\text { Total } \\
\text { water } \\
\text { use, in } \\
\text { billions } \\
\text { of } \\
\text { gallons }\end{array}$ & $\begin{array}{c}\text { Percent } \\
\text { of total } \\
\text { water } \\
\text { use }\end{array}$ \\
\hline 1999 & 333.3 & 6.1 & 311.5 & 9.8 & 43.1 & 0.8 & 12.6 & 0.4 & 825.4 & 15.1 & 161.4 & 5.1 \\
\hline 2000 & 372.1 & 6.6 & 317.5 & 10.1 & 94.0 & 1.7 & 36.8 & 1.2 & $1,170.7$ & 20.6 & 267.0 & 8.5 \\
\hline 2001 & 454.9 & 7.9 & 160.3 & 6.1 & 95.9 & 1.7 & 26.4 & 1.0 & $1,538.9$ & 26.7 & 288.2 & 11.0 \\
\hline 2002 & 373.5 & 5.9 & 160.4 & 5.4 & 258.8 & 4.1 & 71.3 & 2.4 & $1,219.4$ & 19.2 & 218.5 & 7.3 \\
\hline 2003 & 411.0 & 7.0 & 149.4 & 6.5 & 365.7 & 6.2 & 69.5 & 3.0 & $1,205.0$ & 20.4 & 187.6 & 8.2 \\
\hline 2004 & 453.4 & 6.9 & 213.7 & 10.5 & 353.7 & 5.4 & 39.2 & 1.9 & $1,108.3$ & 17.0 & 110.6 & 5.5 \\
\hline 2005 & 277.9 & 3.7 & 116.9 & 3.3 & 424.2 & 5.7 & 133.1 & 3.8 & $1,511.4$ & 20.2 & 228.2 & 6.5 \\
\hline 2006 & 222.1 & 3.2 & 157.4 & 4.5 & 333.3 & 4.8 & 126.2 & 3.6 & $1,601.5$ & 23.2 & 437.2 & 12.5 \\
\hline 2007 & 301.1 & 4.4 & 194.6 & 6.8 & $1,021.1$ & 14.9 & 275.8 & 9.6 & $1,094.2$ & 16.0 & 180.0 & 6.3 \\
\hline 2008 & 270.8 & 3.7 & 123.6 & 3.3 & 816.1 & 11.1 & 334.0 & 8.9 & 688.4 & 9.3 & 144.6 & 3.9 \\
\hline 2009 & 254.0 & 3.5 & 93.2 & 3.3 & 821.5 & 11.2 & 230.2 & 8.1 & 596.2 & 8.1 & 51.8 & 1.8 \\
\hline 2010 & 291.1 & 3.7 & 341.6 & 7.2 & 772.3 & 9.8 & 206.0 & 4.3 & 688.0 & 8.8 & 164.6 & 3.5 \\
\hline 2011 & 291.9 & 3.8 & 257.9 & 6.0 & $1,092.4$ & 14.2 & 470.4 & 11.0 & 886.2 & 11.5 & 204.6 & 4.8 \\
\hline 2012 & 259.5 & 3.4 & 218.5 & 5.2 & 1049.0 & 13.6 & 307.5 & 7.3 & 754.1 & 9.7 & 210.5 & 5.0 \\
\hline 2013 & 259.1 & 3.3 & 127.5 & 4.7 & $1,556.7$ & 20.0 & 338.2 & 12.3 & 445.1 & 5.7 & 60.3 & 2.2 \\
\hline 2014 & 269.2 & 3.3 & 163.8 & 6.7 & 866.8 & 10.7 & 126.3 & 5.2 & 548.7 & 6.8 & 84.8 & 3.5 \\
\hline 2015 & 262.8 & 3.3 & 234.9 & 8.6 & 873.8 & 11.0 & 188.0 & 6.9 & 371.6 & 4.7 & 82.9 & 3.0 \\
\hline 2016 & 252.7 & 3.1 & 189.8 & 6.7 & $1,173.6$ & 14.5 & 296.9 & 10.5 & 590.7 & 7.3 & 83.9 & 3.0 \\
\hline 2017 & 263.1 & 3.2 & 210.1 & 10.6 & 955.1 & 11.7 & 121.9 & 6.2 & 713.2 & 8.8 & 81.2 & 4.1 \\
\hline Average & 309.1 & 4.5 & 197.0 & 6.6 & 682.5 & 9.1 & 179.5 & 5.7 & 924.1 & 13.6 & 170.9 & 5.6 \\
\hline
\end{tabular}




\begin{tabular}{|c|c|c|c|c|c|c|c|c|c|c|c|}
\hline \multicolumn{4}{|c|}{ Other } & \multicolumn{4}{|c|}{ Rice } & \multicolumn{4}{|c|}{ Soybeans } \\
\hline $\begin{array}{c}\text { Total } \\
\text { area, in } \\
\text { thousands } \\
\text { of acres }\end{array}$ & $\begin{array}{c}\text { Percent } \\
\text { of total } \\
\text { crop } \\
\text { area }\end{array}$ & $\begin{array}{c}\text { Total } \\
\text { water } \\
\text { use, in } \\
\text { billions } \\
\text { of } \\
\text { gallons }\end{array}$ & $\begin{array}{c}\text { Percent } \\
\text { of total } \\
\text { water } \\
\text { use }\end{array}$ & $\begin{array}{c}\text { Total } \\
\text { area, in } \\
\text { thousands } \\
\text { of acres }\end{array}$ & $\begin{array}{c}\text { Percent } \\
\text { of total } \\
\text { crop } \\
\text { area }\end{array}$ & $\begin{array}{c}\text { Total } \\
\text { water } \\
\text { use, in } \\
\text { billions } \\
\text { of } \\
\text { gallons }\end{array}$ & $\begin{array}{c}\text { Percent } \\
\text { of total } \\
\text { water } \\
\text { use }\end{array}$ & $\begin{array}{c}\text { Total } \\
\text { area, in } \\
\text { thousands } \\
\text { of acres }\end{array}$ & $\begin{array}{c}\text { Percent } \\
\text { of total } \\
\text { crop } \\
\text { area }\end{array}$ & $\begin{array}{c}\text { Total } \\
\text { water } \\
\text { use, in } \\
\text { billions } \\
\text { of } \\
\text { gallons }\end{array}$ & $\begin{array}{c}\text { Percent } \\
\text { of total } \\
\text { water } \\
\text { use }\end{array}$ \\
\hline 72.3 & 1.3 & 32.8 & 1.0 & $1,934.9$ & 35.5 & $2,080.6$ & 65.7 & $2,247.8$ & 41.2 & 567.1 & 17.9 \\
\hline 77.3 & 1.4 & 40.3 & 1.3 & $1,481.7$ & 26.1 & $1,738.1$ & 55.5 & $2,480.5$ & 43.7 & 731.7 & 23.4 \\
\hline 71.7 & 1.2 & 29.5 & 1.1 & $1,777.9$ & 30.9 & $1,616.5$ & 61.7 & $1,820.1$ & 31.6 & 500.1 & 19.1 \\
\hline 81.7 & 1.3 & 35.1 & 1.2 & $1,845.5$ & 29.0 & $1,923.1$ & 64.6 & $2,577.5$ & 40.5 & 570.3 & 19.1 \\
\hline 122.1 & 2.1 & 44.4 & 1.9 & $1,509.0$ & 25.6 & $1,360.1$ & 59.6 & $2,281.3$ & 38.7 & 471.9 & 20.7 \\
\hline 47.1 & 0.7 & 13.8 & 0.7 & $1,576.7$ & 24.1 & $1,351.1$ & 66.6 & $2,991.1$ & 45.8 & 299.7 & 14.8 \\
\hline 169.4 & 2.3 & 71.2 & 2.0 & $2,397.1$ & 32.1 & $2,465.5$ & 70.0 & $2,688.8$ & 36.0 & 508.4 & 14.4 \\
\hline 268.1 & 3.9 & 136.4 & 3.9 & $1,641.7$ & 23.8 & $1,762.7$ & 50.4 & $2,826.6$ & 41.0 & 876.0 & 25.1 \\
\hline 537.8 & 7.9 & 217.8 & 7.6 & $1,551.8$ & 22.7 & $1,505.7$ & 52.4 & $2,334.9$ & 34.1 & 501.5 & 17.4 \\
\hline 854.6 & 11.6 & 413.3 & 11.0 & $1,763.7$ & 23.9 & $1,731.4$ & 46.3 & $2,987.0$ & 40.5 & 996.4 & 26.6 \\
\hline 301.4 & 4.1 & 110.6 & 3.9 & $1,851.8$ & 25.3 & $1,671.9$ & 58.7 & $3,502.2$ & 47.8 & 692.6 & 24.3 \\
\hline 235.4 & 3.0 & 119.3 & 2.5 & $2,260.4$ & 28.8 & $2,597.3$ & 54.5 & $3,599.9$ & 45.9 & 1338.1 & 28.1 \\
\hline 605.1 & 7.9 & 342.7 & 8.0 & $1,431.0$ & 18.6 & $1,762.7$ & 41.0 & $3,382.2$ & 44.0 & 1257.6 & 29.3 \\
\hline 605.8 & 7.8 & 322.9 & 7.7 & $1,491.9$ & 19.3 & $1,753.8$ & 41.9 & $3,579.7$ & 46.2 & 1375.0 & 32.8 \\
\hline 650.9 & 8.4 & 250.6 & 9.1 & $1,257.6$ & 16.1 & $1,242.9$ & 45.4 & $3,624.2$ & 46.5 & 721.2 & 26.3 \\
\hline 588.4 & 7.3 & 211.6 & 8.6 & $1,867.7$ & 23.0 & 984.7 & 40.2 & $3,964.5$ & 48.9 & 878.7 & 35.9 \\
\hline 616.8 & 7.8 & 201.9 & 7.4 & $1,555.3$ & 19.6 & 810.7 & 29.8 & $4,256.9$ & 53.6 & $1,201.6$ & 44.2 \\
\hline 218.9 & 2.7 & 83.8 & 3.0 & $1,879.9$ & 23.2 & $1,184.8$ & 41.8 & $3,977.6$ & 49.1 & 995.2 & 35.1 \\
\hline 191.1 & 2.3 & 48.1 & 2.4 & $1,339.2$ & 16.5 & 569.1 & 28.8 & $4,674.2$ & 57.5 & 946.5 & 47.9 \\
\hline 332.4 & 4.5 & 143.5 & 4.4 & $1,706.0$ & 24.4 & $1,584.9$ & 51.3 & $3,147.2$ & 43.8 & 812.1 & 26.4 \\
\hline
\end{tabular}




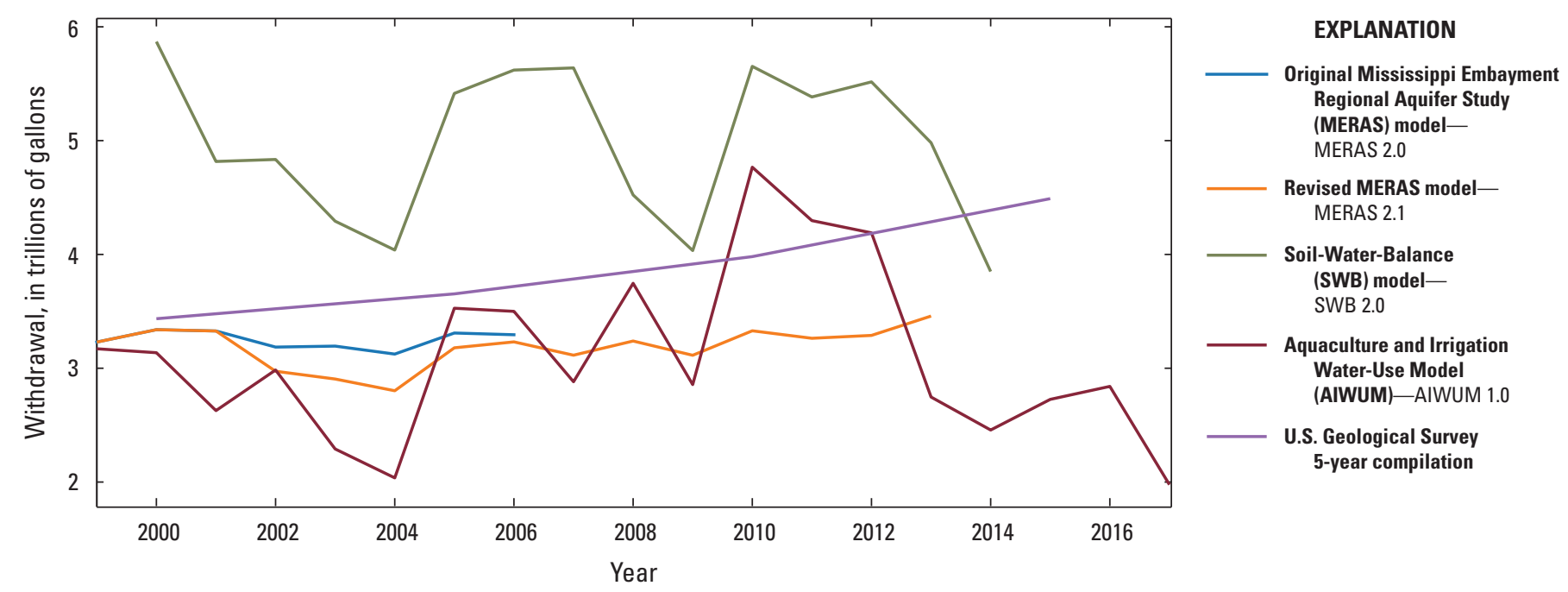

Figure 12. Total water-use estimates for the Mississippi Alluvial Plain study area from the Mississippi Embayment Regional Aquifer Study (MERAS) 2.0, MERAS version 2.1, Soil-Water-Balance (SWB) 2.0, Aquaculture and Irrigation Water-Use Model (AIWUM) 1.0, and U.S. Geological Survey 5-year compilations, 1999 through 2017.

\section{Comparison to SWB 2.0}

Annual total water use from SWB 2.0 for 2000 through 2014 ranged from 4.0 trillion gallons (11.0 billion gallons per day) to 5.9 trillion gallons (16.2 billion gallons per day; fig. 13). Comparison of water use from AIWUM 1.0 and SWB 2.0 indicated that estimates from AIWUM 1.0 were generally smaller (fig. 12), with median PDs typically $>25$ percent but ranging from -53 to 100 percent (fig. 14). Spatially, estimates from AIWUM 1.0 were generally larger than SWB 2.0 west of the Mississippi River in eastern Arkansas and generally smaller within the Mississippi Delta (fig. 15). Temporally, PDs were the largest at the beginning (May) and end (August and September) of the growing season and closer to 0 in the middle of the season (June and July; figs. 14 and 15). Annual total water use generally correlated well between AIWUM 1.0 and SWB 2.0 except for 2007 and 2008 (fig. 12). These two anomalous years are reflected in large PDs for the later part of the growing season (fig. 14). Differences between annual total water-use estimates from AIWUM 1.0 and SWB 2.0 are likely due to errors in crop coefficients. Differences within each year are likely due to differences in irrigation scheduling because scheduling in SWB 2.0 is based on the FAO-56 method, whereas scheduling in AIWUM 1.0 is based on flowmeter data from the YMD.

\section{Comparison to MERAS Models}

Annual total water use from the MERAS 2.0 and 2.1 models from 1999 through 2013 ranged from 3.0 trillion gallons ( 8.2 billion gallons per day) to 3.5 trillion gallons (9.6 billion gallons per day; fig. 12). Comparison between water use from AIWUM 1.0 and well withdrawal in MERAS 2.0 and 2.1 indicated that estimates from AIWUM 1.0 were comparable overall to MERAS 2.0 and 2.1 with the exception of 2003-2004 and 2010-2012 (fig. 12), with median PDs typically about 50 percent but ranging from $>-75$ to 99 percent (fig. 14). Because water use was implemented as a county-wide average evenly during the growing season in MERAS 2.0 and estimates in AIWUM 1.0 were consistently smaller at the beginning of each growing season and larger at the end of each growing season, PDs were consistently larger (MERAS models estimated higher water use than AIWUM) at the beginning of each growing season and smaller (AIWUM estimated higher water use than MERAS models) at the end of each growing season (fig. 16). Median PDs between AIWUM 1.0 and MERAS models were generally $>50$ percent from 1999 through 2006, but decreased below -60 percent for 2007 , 2011, and 2012 (fig. 14). 


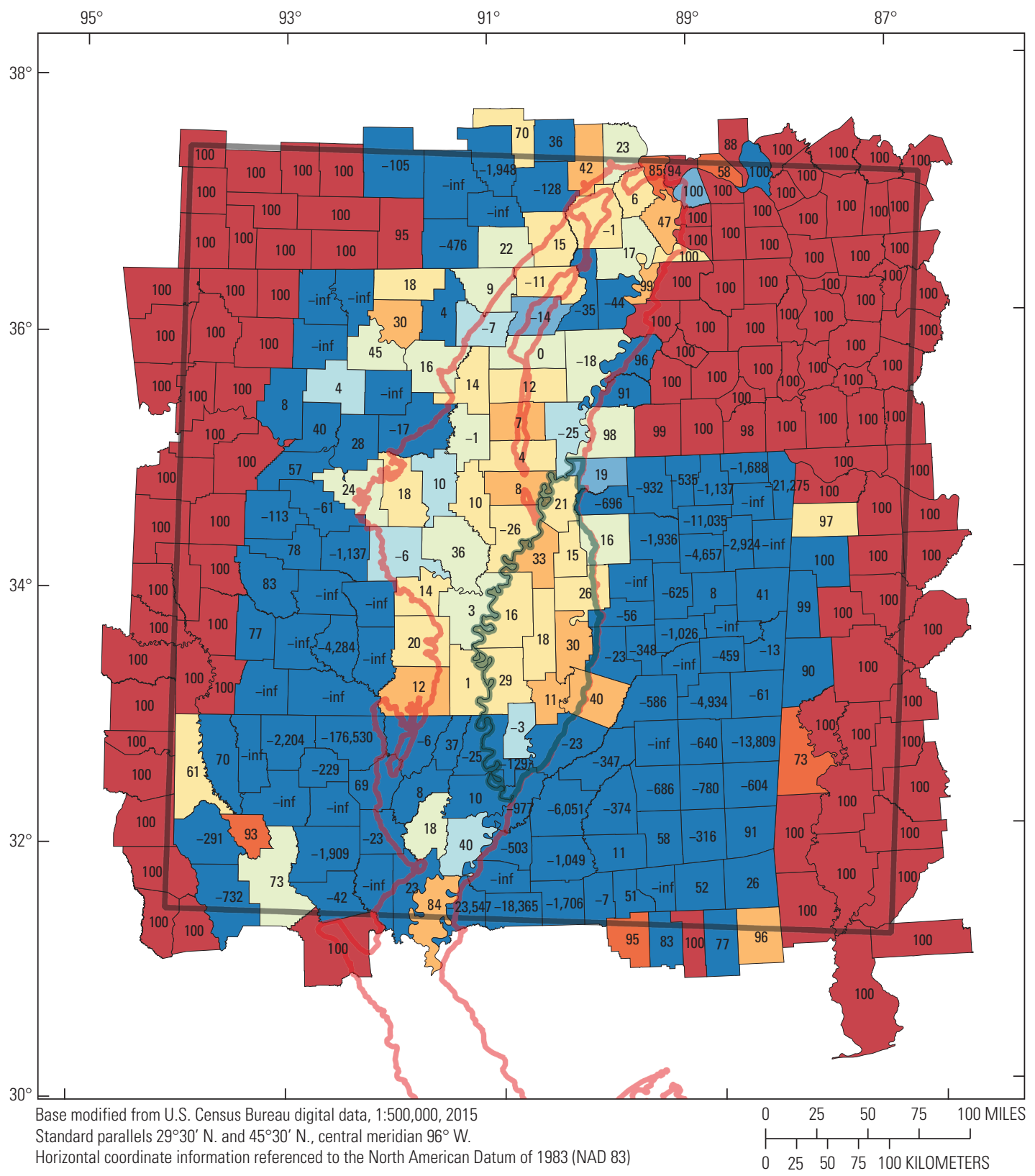

\section{EXPLANATION}

[Percent difference in irrigated area-Values of "-inf" indicate the U.S. Geological Survey 5-year compilation reported no irrigated area but Aquaculture and Irrigation Water-Use Model (AIWUM) estimated water use in the county. Values of " 100 " indicate the 5 -year compilation reported irrigated area but AIWUM estimated no water use]

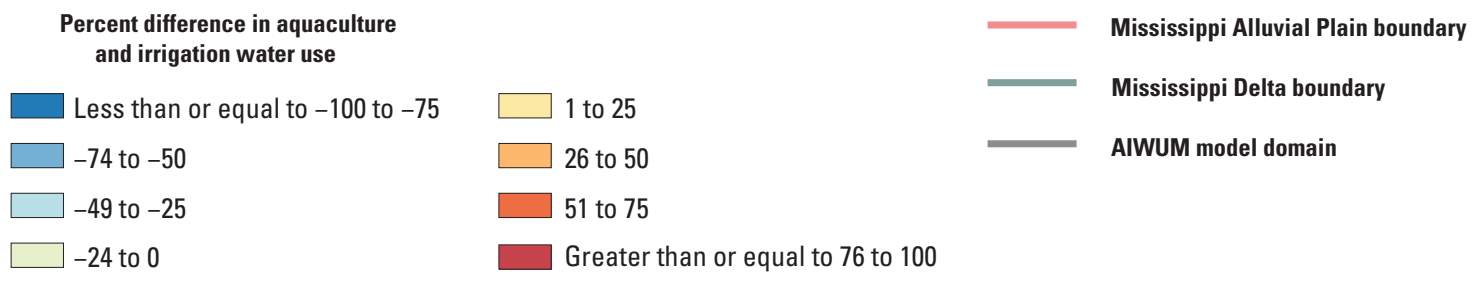

Figure 13. Percent difference between county-level estimated aquaculture and irrigation water use and irrigated area from Aquaculture and Irrigation Water-Use Model (AIWUM) 1.0 and compiled, estimated water use from the U.S. Geological Survey 5-year compilations for the Mississippi Alluvial Plain (MAP) study area for $A, 2005 ; B, 2010$; and $C$, 2015. Negative percent difference indicates estimates from AIWUM are larger; whereas, positive percent differences indicate values from the 5 -year compilation are larger. Large sections of large percent differences in $A$ are the result of missing estimates due to the absence of the Cropland Data Layer in those areas for 2005. 


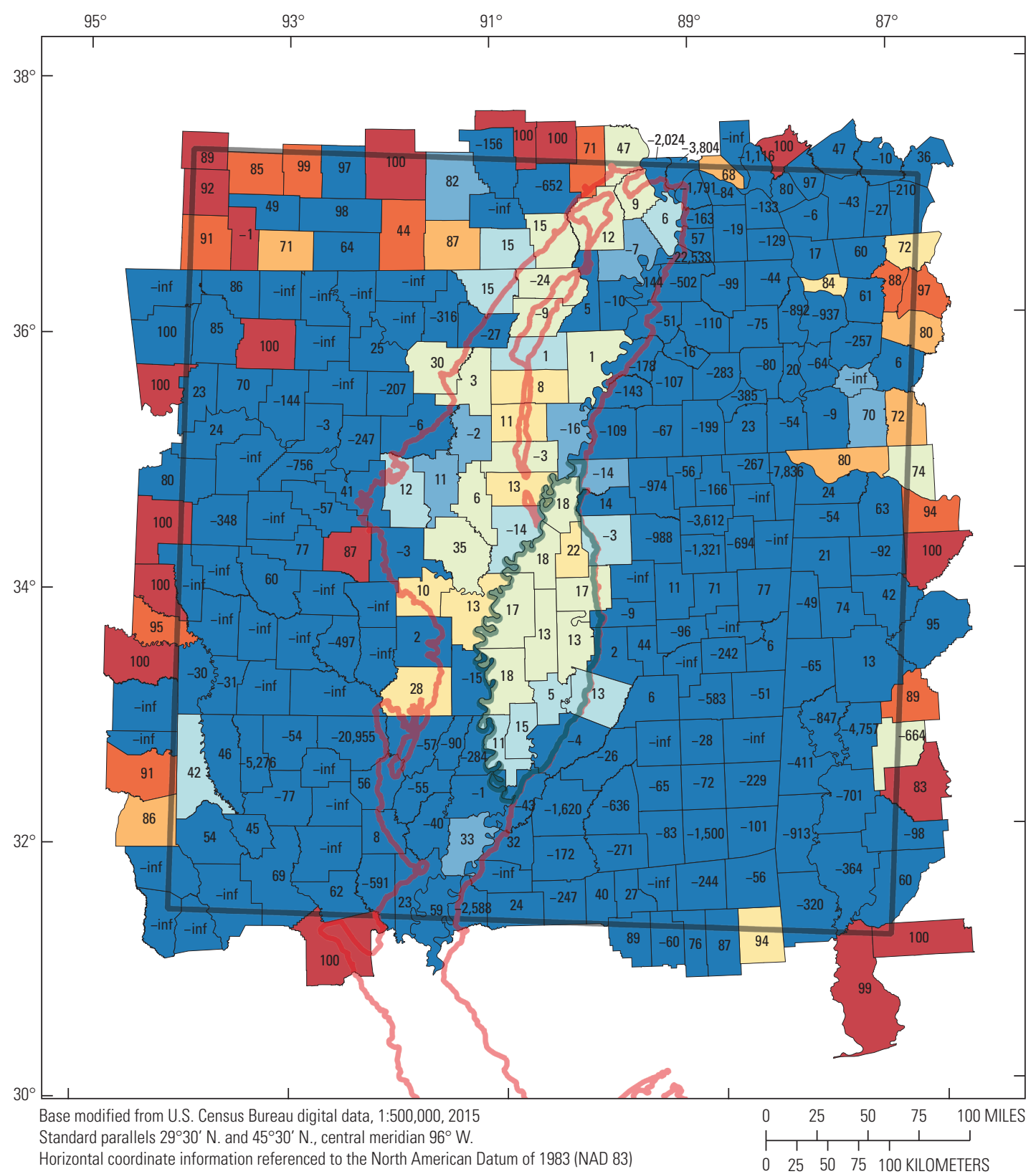

EXPLANATION

[Percent difference in irrigated area-Values of "-inf" indicate the U.S. Geological Survey 5-year compilation reported no irrigated area but Aquaculture and Irrigation Water-Use Model (AIWUM) estimated water use in the county. Values of "100" indicate the 5-year compilation reported irrigated area but AIWUM estimated no water use]

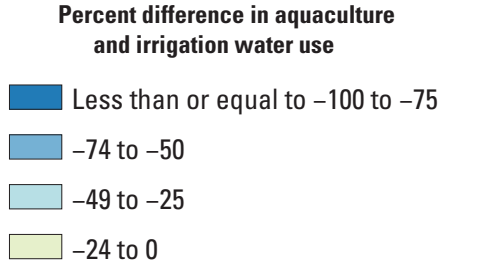

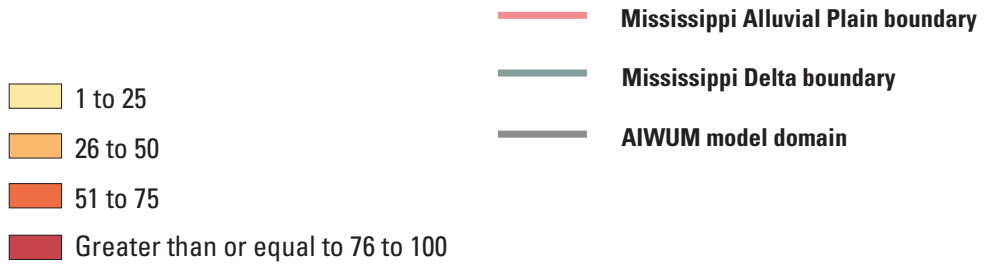

Figure 13.-Continued. Percent difference between county-level estimated aquaculture and irrigation water use and irrigated area from Aquaculture and Irrigation Water-Use Model (AIWUM) 1.0 and compiled, estimated water use from the U.S. Geological Survey 5-year compilations for the Mississippi Alluvial Plain (MAP) study area for $A, 2005 ; B, 2010$; and $C, 2015$. Negative percent difference indicates estimates from AIWUM are larger; whereas, positive percent differences indicate values from the 5-year compilation are larger. Large sections of large percent differences in $A$ are the result of missing estimates due to the absence of the Cropland Data Layer in those areas for 2005. 


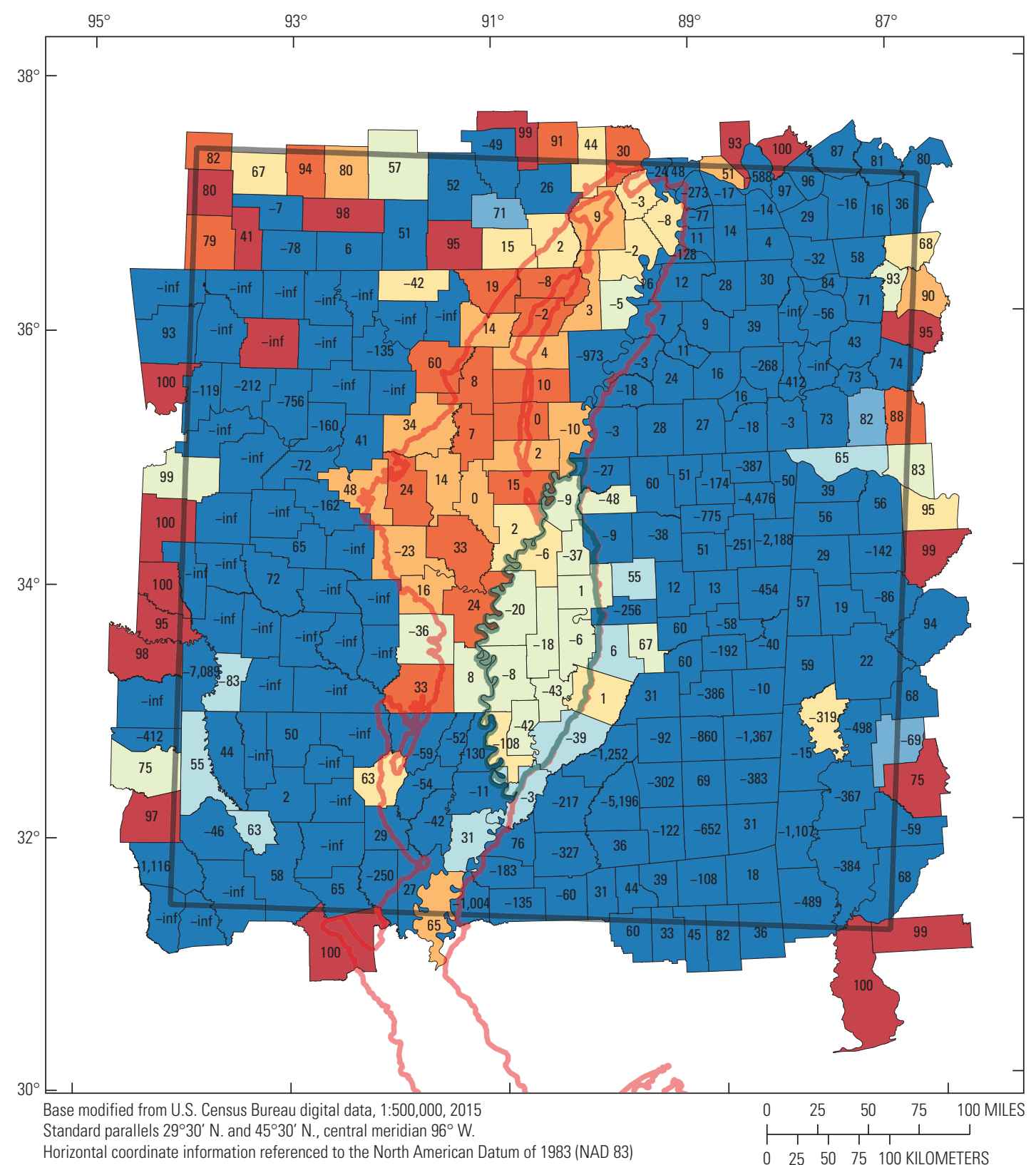

EXPLANATION

[Percent difference in irrigated area-Values of "-inf" indicate the U.S. Geological Survey 5-year compilation reported no irrigated area but Aquaculture and Irrigation Water-Use Model (AIWUM) estimated water use in the county. Values of "100" indicate the 5-year compilation reported irrigated area but AIWUM estimated no water use]
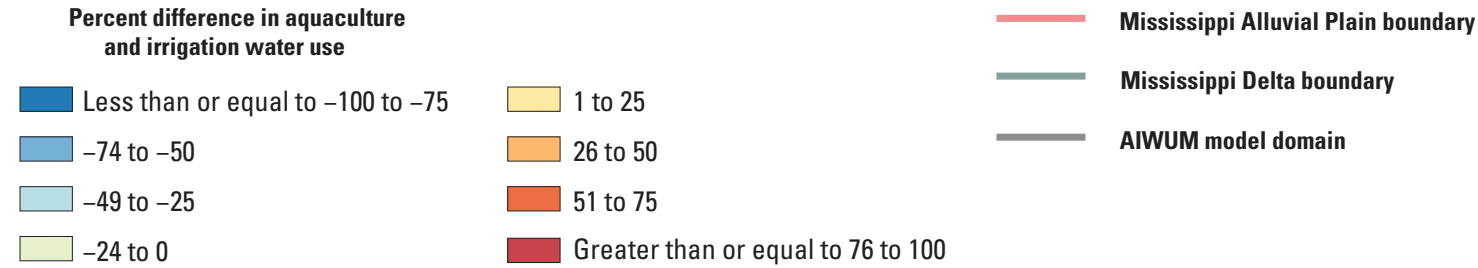

Figure 13.-Continued. Percent difference between county-level estimated aquaculture and irrigation water use and irrigated area from Aquaculture and Irrigation Water-Use Model (AIWUM) 1.0 and compiled, estimated water use from the U.S. Geological Survey 5-year compilations for the Mississippi Alluvial Plain (MAP) study area for $A, 2005 ; B, 2010$; and $C$, 2015. Negative percent difference indicates estimates from AIWUM are larger; whereas, positive percent differences indicate values from the 5-year compilation are larger. Large sections of large percent differences in $A$ are the result of missing estimates due to the absence of the Cropland Data Layer in those areas for 2005. 


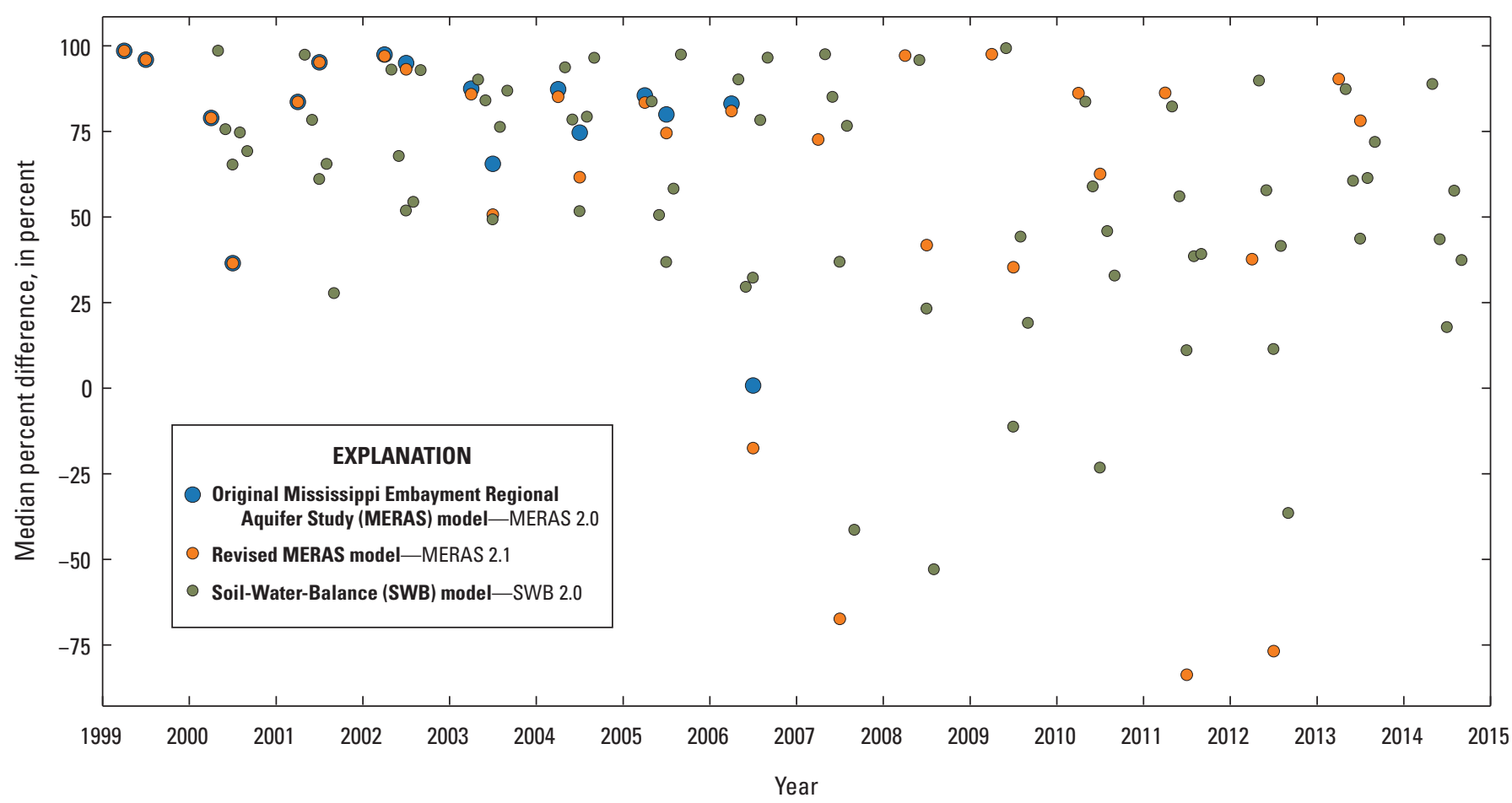

Figure 14. Median percent differences of total water use between Aquaculture and Irrigation Water-Use Model (AIWUM) 1.0 and Soil-Water-Balance (SWB) 2.0 and Mississippi Embayment Regional Aquifer Study (MERAS) models for monthly (SWB 2.0) and quarterly (MERAS 2.0 and 2.1) time steps.

Estimates from AIWUM 1.0 were generally much smaller than the withdrawal in MERAS 2.0 and 2.1 at the beginning of each growing season, with mixed agreement (areas where estimates from AIWUM 1.0 were smaller and other areas where AIWUM 1.0 was larger than the MERAS model) at the end of each growing season. The refinement in water use in the Mississippi Delta that occurred in MERAS 2.1 is apparent when compared to MERAS 2.0 in figure 16. PDs outside the Mississippi Delta are similar in MERAS 2.0 and 2.1; however, within the delta, PDs differ between MERAS 2.0 and 2.1, and MERAS 2.1 shows very large positive PDs (typically > about 75 percent) at the beginning of the growing season (AprilJune) and very negative PDs (typically $<$ about -25 percent) at the end of the growing season (July-September). Although there are large disagreements in estimates in the Mississippi Delta within each part of the growing season, the annual total water use in AIWUM 1.0 and MERAS 2.1 is comparable because both are based on the same water-use data from the YMD in the Mississippi Delta.

The relative differences between water use from AIWUM and MERAS models within portions of the growing season are a result of AIWUM 1.0 estimates that vary month-to-month, whereas MERAS 2.0 and 2.1 essentially apply a constant water-use rate during the entire growing season. The large disagreement between AIWUM 1.0 and the MERAS models for entire growing seasons likely is a result of the methods used to develop the water-use estimates. Water-use estimates in MERAS 2.0 and for portions of MERAS 2.1 were developed from county-scale estimates distributed to model cells, whereas AIWUM estimates were developed at a much smaller resolution from 30-m crop-type data, 250-m irrigated lands masks, and flowmeter data. 

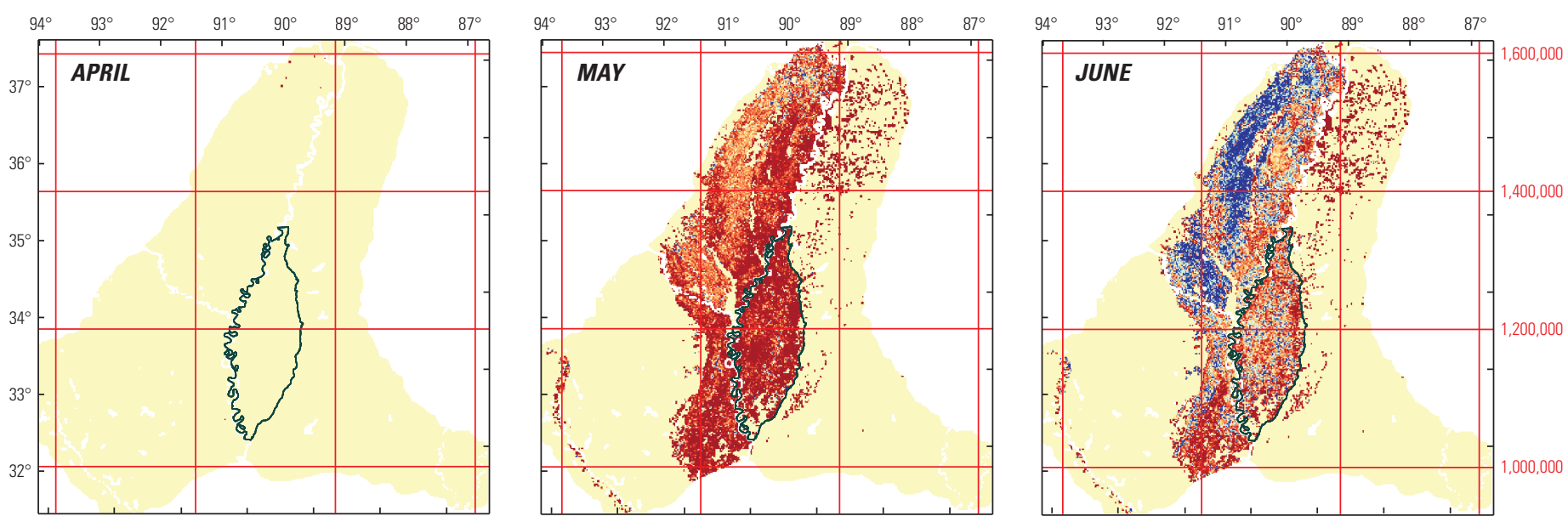

\section{EXPLANATION}

[SWB, Soil-Water-Balance; AIWUM, Aquaculture and Irrigation Water-Use Model]

Percent difference of estimated irrigation water use

Equal to or greater than 100 (SWB indicates water use and AIWUM does not) 75

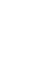

50

$-25$
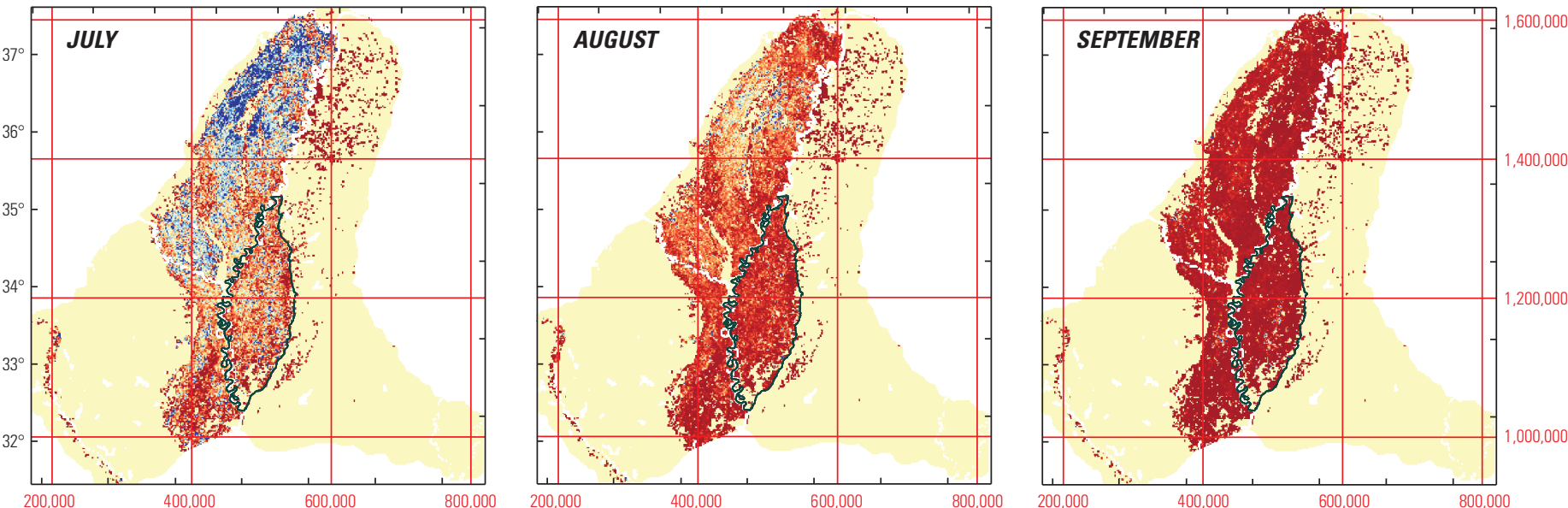

O (SWB and AIWUM estimate the same water use)

$-25$

$-50$

$-75$

Less than or equal to -100 (AIWUM indicates water use and SWB does not)

Base modified from U.S. Census Bureau digital data, 1:500,000, 2015 Standard parallels $29^{\circ} 30^{\prime} \mathrm{N}$. and $45^{\circ} 30^{\circ} \mathrm{N}$., central meridian $96^{\circ} \mathrm{W}$.

Secondary grid displays Albers Equal-Area Conic projection, in meters

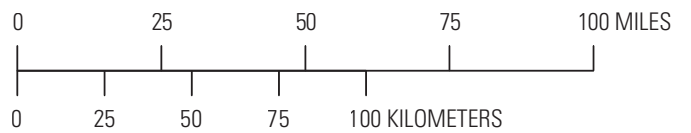

Mississippi Delta boundary

$\begin{array}{lllll}0 & 25 & 50 & 75 & 100 \text { KILOMETERS }\end{array}$

Figure 15. Percent difference between estimated water use from Aquaculture and Irrigation Water-Use Model (AIWUM) 1.0 and Soil-Water-Balance (SWB) 2.0 during the growing season (April through September), 2006. Percent differences in water use in April are practically 0 but reported here because of small water use estimated in SWB 2.0 in the northern portion of the model domain. 

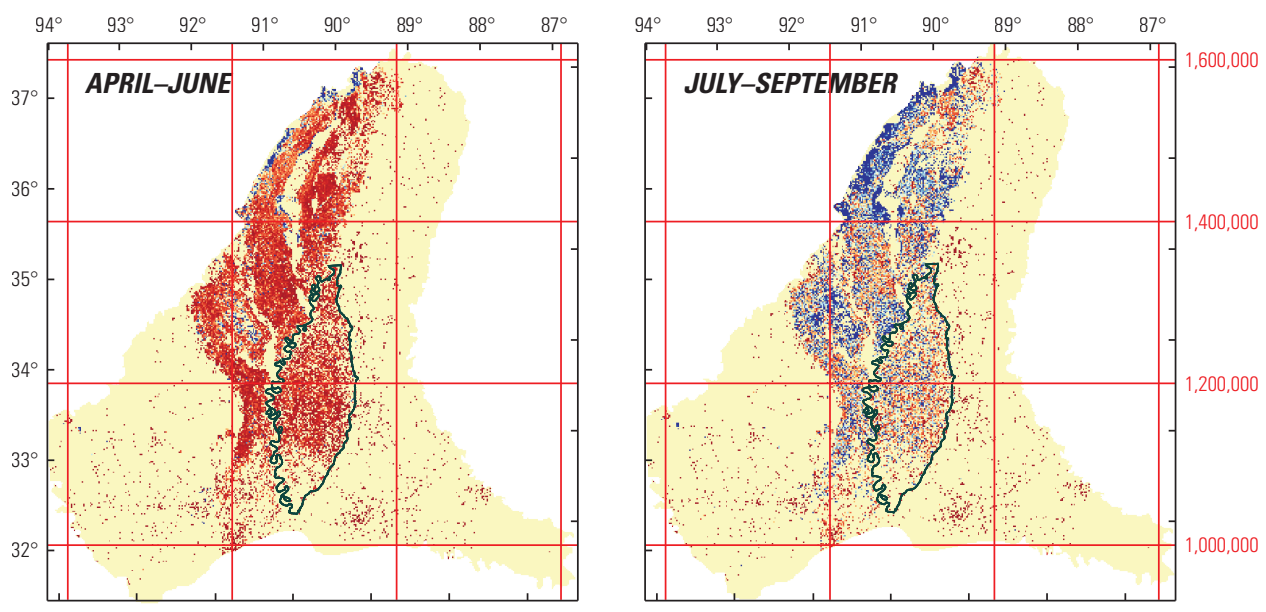

EXPLANATION
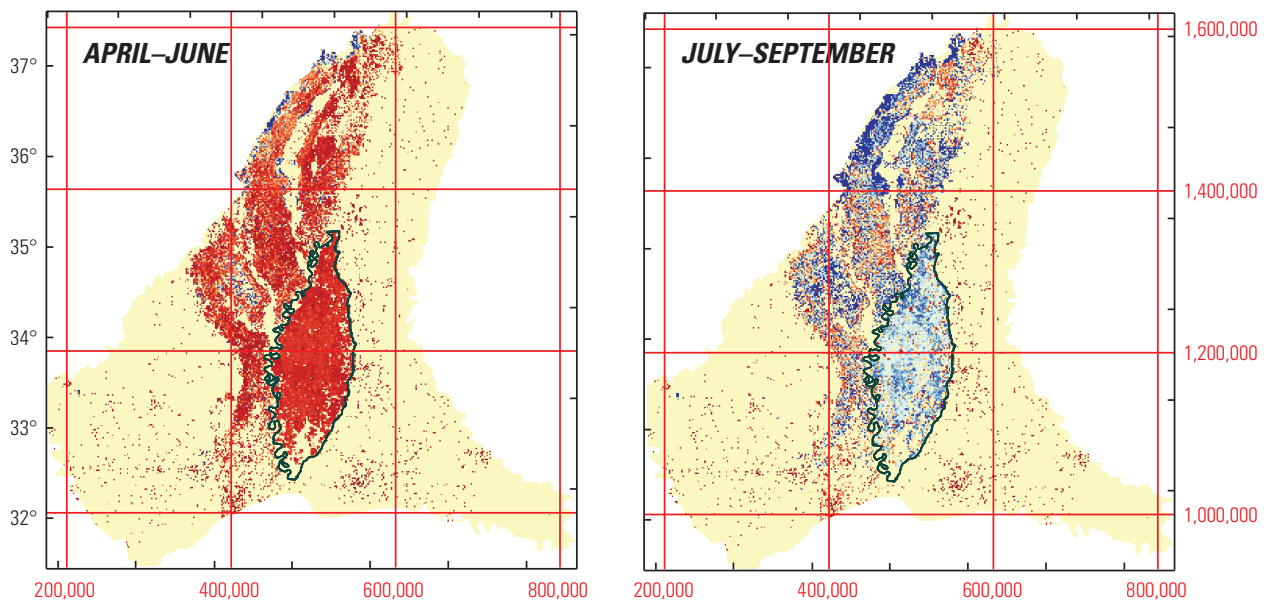

Base modified from U.S. Census Bureau digital data, 1:500,000, 2015

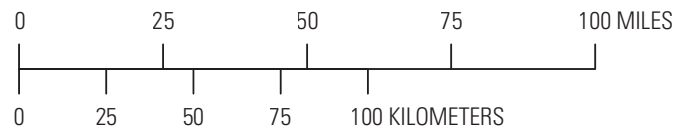

[MERAS, Mississippi Embayment Regional Aquifer Study; AIWUM, Aquaculture and [rrigation Water-Use Model]

Percent difference of estimated irrigation water use

Equal to or greater than 100 (MERAS indicates water us and AIWUM does not

50

25

0 (MERAS and AIWUM estimate the same water use)

$-25$

$-50$

$-75$

75

Less than or equal to -100 (AIWUM indicates water use and MERAS does not)

Standard parallels $29^{\circ} 30^{\prime} \mathrm{N}$. and $45^{\circ} 30^{\prime} \mathrm{N}$., central meridian $96^{\circ} \mathrm{W}$.

Secondary grid displays Albers Equal-Area Conic projection, in meters

Horizontal coordinate information referenced to the North American Datum of 1983 (NAD 83)

$$
25
$$

75100 KILOMETERS

Figure 16. Percent difference for April through June and July through September 2006 between estimated water use from Aquaculture and Irrigation Water-Use Model (AIWUM) 1.0 and parameterized groundwater withdrawal from $A$, the original Mississippi Embayment Regional Aquifer Study (MERAS) model 2.0 and $B$, the MERAS model 2.1 with Yazoo Mississippi Delta Joint Water Management District flowmeter data incorporated. 


\section{Strengths and Weaknesses of AIWUM 1.0}

Because water-use estimates from the 5-year compilation and those used in the MERAS models are primarily countyscale data, estimates in SWB 2.0 are substantially higher than all other estimates, and AIWUM is the only model to use measured withdrawal data and orders-of-magnitude greater resolution datasets, AIWUM likely represents the most accurate model of agricultural water use to date in the MAP. The first version of AIWUM presented in this report was applied to the MAP study area but can be implemented at the CONUS scale. The model programmatically ingests CONUS-scale data including crop-type distribution, climate, and irrigated lands, calculates aquaculture and irrigation water use at a fine, spatial (30 or $100 \mathrm{~m}$ ) and temporal resolution (monthly), and provides gridded estimates that can be directly used in groundwater models or other models that require aquaculture and irrigation water-use estimates on a monthly time scale. This water-use model provides a nationally consistent framework to estimate aquaculture and irrigation water use which can be updated quickly as newer and better data become available (for example, additional flowmeter data or improved crop-type data).

Although AIWUM 1.0 can provide water-use estimates to groundwater models in the study area, limitations of AIWUM 1.0 do exist. Seven are listed here. First, AIWUM 1.0 is primarily driven by measured flowmeter data collected in the Mississippi Delta that require extrapolation to locations outside the domain of the flowmeter data, resulting in potentially large errors. AIWUM 1.0 has successfully been tested over the entire CONUS, but for AIWUM to provide accurate estimates outside the MAP study area, additional flowmeter data or regional crop-specific withdrawal rates would need to be incorporated. AIWUM 1.0 only estimates water demand based on data reported for aquaculture, cotton, corn, rice, and soybeans; application of AIWUM 1.0 in areas dominated by other crop types requires crop-specific information to be used to maintain accuracy. All other crops are derived from an average of these crops. Second, because of a lack of better available irrigated-lands data for the model period, the distribution of irrigated lands in AIWUM 1.0 is based on datasets available for 2002, 2007, and 2012, and model years between those years assume a constant distribution of irrigated lands. Errors in the designation of irrigated lands is one of the largest forms of error in AIWUM 1.0 because all water use outside of areas identified as irrigated is set to zero, and an improved irrigated-lands dataset would substantially improve the accuracy of the model. Third, AIWUM 1.0 is limited temporally to the period covered by the CDL (1999 through 2017) and the irrigated-lands datasets, and crop-type data are provided only for a portion of the CONUS for years 1999 through 2007. Continuous crop-type and irrigated-lands datasets for the CONUS for years before, during, and after 1999 through 2017 for the MAP study area would improve estimates from 1999 through 2017 and allow for hind- and forecasting of water-use estimates beyond 1999 through 2017, which would be useful in calibration and scenario evaluation in groundwater models. Fourth, AIWUM 1.0 only uses measured data to derive crop-specific withdrawal rates, making it difficult to accurately hind- or forecast water use, a particularly useful capability in groundwater modeling; development of methods that incorporate explanatory variables (such as precipitation and temperature) to predict water use at each model node would allow for improved hind- and forecasting. Fifth, the source of water in AIWUM 1.0 is assumed to be solely groundwater; within the MAP study this is likely a fair assumption; however, for AIWUM 1.0 to be more applicable to the CONUS, improvements would be needed to estimate areas where water would be from surface-water sources. Sixth, system efficiencies and conveyance losses, which likely explain some of the variation in crop-specific withdrawal rates, are not currently accounted for in AIWUM 1.0; incorporation of information on the spatial distribution of different irrigation systems (for example, furrow or center-pivot), crop-specific withdrawal rates associated with each system type, and a metric or surrogate of conveyance loss could improve model accuracy, especially in areas that do not rely on a single irrigation system type. Finally, AIWUM 1.0 assumes that double cropping, the sequential irrigation and harvesting of two crops within the same field, does not occur, and an average crop-specific withdrawal rate is used for all pixels identified as double cropped.

\section{Summary}

Water use is one of the critical elements of any groundwater model, yet it remains one of the most uncertain components in many groundwater models. The objective of this research was development of a model that better and consistently estimates aquaculture and irrigation water use at the spatial and temporal scale needed to more accurately represent water use in groundwater models. In this report, the initial version of Aquaculture and Irrigation Water-Use Model (AIWUM 1.0) was described, and the output was compared to reported water-use data, an independent water-use model, and groundwater models within the Mississippi Alluvial Plain (MAP) study area.

Annual total water-use estimates from 1999 through 2017 from AIWUM 1.0 in the study area ranged from 5.42 billion gallons per day to 13.1 billion gallons per day. On average, a majority (about 51 percent) of the water use was applied to rice, followed by soybeans (about 26 percent), and all other uses each accounted for less than 10 percent of total water use each. Annual total water-use estimates from the independent estimates (5-year compilations, Soil-Water-Balance [SWB] 2.0, Mississippi Embayment Regional Aquifer Study [MERAS] 2.0, and MERAS 2.1) ranged from about 8 to 16 billion gallons per day. Comparisons indicated that annual total water-use estimates from AIWUM 1.0 were generally smaller than all other sources of water-use data, but the 
temporal trend of water use correlated well with SWB 2.0. Relative differences between AIWUM 1.0 and other models within a given growing season are likely the result of differences in irrigation scheduling because scheduling in SWB 2.0 is based on the Food and Agriculture Organization-56 method and irrigation in both MERAS models is constant within each growing season, whereas scheduling in AIWUM 1.0 is based on flowmeter data from the Yazoo Mississippi Delta Joint Water Management District. Although there are large disagreements in water-use estimates between the AIWUM 1.0 and MERAS 2.1 models in the Mississippi Delta within each part of the growing season, the annual total water use calculated by the models is comparable because both use the same water-use data from the Yazoo Mississippi Delta Joint Water Management District in the Mississippi Delta. Because water-use estimates from the 5-year compilation and those used in the MERAS models are primarily county-scale data, estimates in SWB 2.0 are substantially higher than all other estimates, and AIWUM is the only model to use measured withdrawal data and orders-of-magnitude greater resolution datasets, AIWUM likely represents the most accurate model of agricultural water use to date in the MAP.

AIWUM 1.0 has the capability for use as a uncalibrated national-scale water-use model; however, confidence in water-use estimates produced from AIWUM 1.0 in areas outside the MAP study area, where the model is calibrated, would be low, but site- or region-specific data could be used to calibrate the model in other areas. The water-use output from AIWUM could be used in other models at all scales (for example, local, regional, national) and provides a nationally consistent methodology in estimating water use driven by regionally representative crop-specific withdrawal rates, which are the onus of the model user to provide. Future versions of AIWUM could potentially seek to address each of the limitations of AIWUM 1.0, using improved prediction techniques and data inputs to incrementally produce a better estimate of water use in space and time while providing estimates to regional and national models that rely on aquaculture and irrigation water use as inputs.

\section{References Cited}

Alhassan, M., Lawrence, C., Richardson, S., and Pindilli, E., 2019, The Mississippi Alluvial Plain aquifers-An engine for economic activity: U.S. Geological Survey Fact Sheet 2019-3003, 4 p., accessed March 30, 2020, at https://doi.org/10.3133/fs20193003.

Allen, R.G., Pereira, L.S., Raes, D., and Smith, M., 1998, FAO Irrigation and drainage paper No. 56-Crop evaporation: Food and Agriculture Organization of the United Nations, 210 p., accessed March 30, 2020, at http://academic .uprm.edu/abe/backup2/tomas/fao\%2056.pdf.
Bakker, M., Post, V., Langevin, C.D., Hughes, J.D., White, J.T., Starn, J.J., and Fienen, M.N., 2016, Scripting MODFLOW model development using Python and FloPy: Ground Water, v. 54, no. 5, p. 733-739, accessed March 30, 2020, at https://doi.org/10.1111/gwat.12413.

Barlow, J.R.B., and Clark, B.R., 2011, Simulation of water-use conservation scenarios for the Mississippi Delta using an existing regional groundwater flow model: U.S. Geological Survey Scientific Investigations Report 2011-5019, 14 p., accessed March 30, 2020, at https://doi.org/10.3133/sir2011 5019 .

Brown, J., and Pervez, M.S., 2014, Merging remote sensing data and national agricultural statistics to model change in irrigated agriculture: Agricultural Systems, v. 127, p. 28-40, accessed March 30, 2020, at https://doi.org/10.1016/ j.agsy.2014.01.004.

Brown, J.F., Maxwell, S.K., and Pervez, M.S., 2009, Mapping irrigated lands across the United States using MODIS satellite imagery, in Thenkabail P.S., and others, eds., Remote sensing of global croplands for food security: Boca Raton, Fla., CRC Press, 22 p., accessed March 30, 2020, at https://doi.org/10.1201/9781420090109.

Clark, B.R., and Hart, R.M., 2009, The Mississippi Embayment Regional Aquifer Study (MERAS) Documentation of a groundwater-flow model constructed to assess water availability in the Mississippi embayment: U.S. Geological Survey Scientific Investigations Report 2009-5172, 61 p., accessed March 30, 2020, at https://doi.org/10.3133/sir20095172.

Clark, B.R., Westerman, D.A., and Fugitt, D.T., 2013, Enhancements to the Mississippi Embayment Regional Aquifer Study (MERAS) groundwater-flow model and simulations of sustainable water-level scenarios: U.S. Geological Survey Scientific Investigations Report 2013-5161, 29 p., accessed March 30, 2020, at https://doi.org/10.3133/sir20135161.

Colby, S.L., and Ortman, J.M., 2015, Projections of the size and composition of the US population-2014 to 2060 - Current Population Reports: U.S. Census Bureau Report p25-1143., 13 p., accessed March 30, 2020, at https:/census.gov/library/publications/2015/demo/p251143.html.

Daly, C., Neilson, R.P., and Phillips, D.L., 1994, A statisticaltopographic model for mapping climatological precipitation over mountainous terrain: Journal of Applied Meteorology, v. 33, no. 2, p. 140-158, accessed March 30, 2020, at https://doi.org/10.1175/1520-0450(1994)033\%3C0 140:ASTMFM\%3E2.0.CO;2. 
Demissie, Y., Valocchi, A., Cai, X., Brozovic, N., Senay, G., and Gebremichael, M., 2015, Parameter estimation for groundwater models under uncertain irrigation data: Ground Water, v. 53, no. 4, p. 614-625, accessed March 30, 2020, at https://doi.org/10.1111/gwat.12235.

Falcone, J.A., 2015, U.S. conterminous wall-to-wall anthropogenic land use trends (NWALT), 1974-2012: U.S. Geological Survey Data Series 948, 33 p. plus appendixes 3-6 as separate files, accessed March 30, 2020, at http://doi.org/10.3133/ds948.

Falcone, J.A., and LaMotte, A.E., 2016, National 1-kilometer rasters of selected Census of Agriculture statistics allocated to land use for the time period 1950 to 2012: U.S. Geological Survey data release, https://doi.org/10.5066/ F70R9MHS.

Fowler, S.R., and Rodekohr, D., 2015, Estimates of future agricultural water withdrawal in Alabama: Auburn University Water Resources Center, 31 p., accessed November 20, 2020, at https://adeca.alabama.gov/Divisions/ owr/watermanagement/2017\%20OWR\%20Surface $\% 2$ 0Water\%20Assessment/Appendix\%20C\%20Complete.pdf.

GDAL contributors, 2019, GDAL/OGR Geospatial Data Abstraction software Library, Open Source Geospatial Foundation, accessed March 30, 2020, at https://gdal.org.

Haugh, C.J., 2019, The Mississippi embayment regional aquifer system (MERAS) groundwater-flow model, version 2.1, in U.S. Geological Survey data release, https://doi.org/ 10.5066/P9906VM5.

Haugh, C.J., Killian, C.D., and Barlow, J.R.B., 2019, Simulation of water management scenarios for the Mississippi Delta: U.S. Geological Survey Scientific Investigation Report 2019-5116, accessed March 30, 2020, at https://doi.org/10.3133/sir20195116.

Hoyer, S., and Hamman, J., 2017, Xarray-N-D labeled arrays and datasets in Python: Journal of Open Research Software, v. 5, no. 1, 10 p., accessed November 20, 2020, at http://doi.org/10.5334/jors. 148.

Kebede, H., Fisher, D.K., Sui, R., and Reddy, K.N., 2014, Irrigation methods and scheduling in the delta region of Mississippi-Current status and strategies to improve irrigation efficiency: American Journal of Plant Sciences, v. 5, no. 20, p. 2917-2928, accessed March 30, 2020, at https://doi.org/10.4236/ajps.2014.520307.

Massey, J.H., Mark Stiles, C., Epting, J.W., Shane Powers, R., Kelly, D.B., Bowling, T.H., Leighton Janes, C., and Pennington, D.A., 2017, Long-term measurements of agronomic crop irrigation made in the Mississippi delta portion of the lower Mississippi River Valley: Irrigation Science, v. 35, no. 4, p. 297-313, accessed March 30, 2020, at https://doi.org/10.1007/s00271-017-0543-y.
Maupin, M.A., and Barber, N.L., 2005, Estimated withdrawals from principal aquifers in the United States, 2000: U.S. Geological Survey Circular 1279, 46 p., accessed March 30, 2020, at https://doi.org/10.3133/cir1279.

McKinney, W., 2010, Data structures for statistical computing in Python, in Proceedings of the 9th Python in Science Conference, Austin, TX, p. 51-56, accessed March 30, 2020, at https://www.semanticscholar.org/paper/Data-Structuresfor-Statistical-Computing-in-Python-McKinney/f6dac1c52d 3b07c993fe52513b8964f86e8fe381.

National Academies of Sciences, Engineering, and Medicine, 2018, Future water priorities for the Nation-Directions for the U.S. Geological Survey Water Mission Area: Washington, D.C., The National Academies Press, 110 p., accessed March 30, 2020, at https://doi.org/10.17226/2 5134 .

Pervez, M.S., and Brown, J.F., 2010, Mapping irrigated lands at 250-m scale by merging MODIS data and National Agricultural Statistics: Remote Sensing, v. 2, no. 10, p. 2388-2412, accessed March 30, 2020, at https://doi.org/ $10.3390 /$ rs 2102388 .

Powers, S., 2007, Agricultural water use in the Mississippi Delta: YMD Joint Water Management District, 4 p., accessed March 30, 2020, at https://www.ymd.org/ publications.htm.

Seabold, S., and Perktold, J., 2010, Statsmodel-Econometric and statistical modeling with python, in Proceedings of the 9th Python in Science Conference, SciPy, p. 61, accessed March 30, 2020, at https://conference.scipy.org/ proceedings/scipy2010/pdfs/seabold.pdf.

U.S. Census Bureau, 2017, TIGER/Line ${ }^{\circledR}$ Shapefiles: accessed March 30, 2020, at https://www.census.gov/geographies/ mapping-files/time-series/geo/tiger-line-file.html.

U.S. Geological Survey, 2019a, USGS Water Data for the Nation: U.S. Geological Survey National Water Information System database, accessed May 10, 2018, at http://doi.org/10.5066/F7P55KJN.

U.S. Geological Survey, 2019b, National Hydrography Dataset (ver. USGS National Hydrography Dataset Best Resolution [NHD] for Hydrologic Unit [HU] 4 - 2001 [published 20191002]): USGS National Hydrography web page, accessed November 20, 2020, at https://www.usgs.gov/corescience-systems/ngp/national-hydrography/access-nationalhydrography-products.

U.S. Geological Survey, 2020, National water censusWater use: USGS Water Resources web page, accessed on November 20, 2020, at https://www.usgs.gov/mission-areas/ water-resources/science/national-water-census-water-use? qt-science_center_objects $=0 \#$ qt-science_center_objects. 
U.S. Department of Agriculture, 2020, CropScape and Cropland Data Layer-Metadata: U.S. Department of Agriculture National Agricultural Statistics Service webpage, accessed March 30, 2020, at https:/www.nass .usda.gov/Research_and_Science/Cropland/metadata/ meta.php.

Westenbroek, S.M., Nielsen, M.G., and Ladd, D.E., 2021, OFR 2021-1008 MODEL OUTPUT-Soil-Water-Balance net infiltration and irrigation water use output datasets for the Mississippi Embayment Regional Aquifer Study Area, 1915 to 2018: U.S. Geological Survey data release, accessed March 30, 2020, at https://doi.org/10.5066/P9U4 $84 \times 5$.

Westenbroek, S.M., Engott, J.A., Kelson, V.A., and Hunt, R.J., 2018, SWB Version 2.0-A soil-water-balance code for estimating net infiltration and other water-budget components: U.S. Geological Survey Techniques and Methods, book 6, chap. A59, 118 p., accessed March 30, 2020, at https://doi.org/10.3133/tm6A59.

Wilson, J.L., 2021, Aquaculture and Irrigation Water-Use Model (AIWUM) version 1.0 estimates and related datasets for the Mississippi Alluvial Plain, 1999-2017: U.S. Geological Survey data release, https://doi.org/10.5066/ P9JMO9G4.
For more information about this publication, contact: Director, USGS Central Midwest Water Science Center 405 North Goodwin

Urbana, IL 61801

217-328-8747

For additional information, visit: https://www.usgs.gov/centers/cm-water

Publishing support provided by the

Rolla Publishing Service Center 


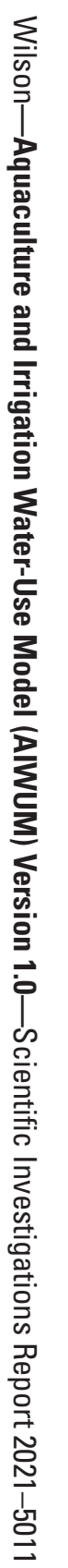

